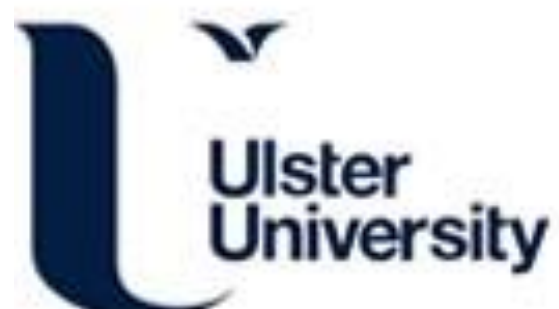

\section{Valorization of biodiesel side stream waste glycerol for rhamnolipids production by Pseudomonas aeruginosa RS6}

Baskaran, S. M., Zakaria , M. R., Sabri, A. S. M. A., Mohamed, M. S., Wasoh, H., Toshinari, M., Hassan, M. A., \& Banat, I. M. (2021). Valorization of biodiesel side stream waste glycerol for rhamnolipids production by Pseudomonas aeruginosa RS6. Environmental Pollution, 276, [116742]. https://doi.org/10.1016/j.envpol.2021.116742

Link to publication record in Ulster University Research Portal

Published in:

Environmental Pollution

Publication Status:

Published (in print/issue): 01/05/2021

DOI:

10.1016/j.envpol.2021.116742

\section{Document Version}

Publisher's PDF, also known as Version of record

\section{General rights}

Copyright for the publications made accessible via Ulster University's Research Portal is retained by the author(s) and / or other copyright owners and it is a condition of accessing these publications that users recognise and abide by the legal requirements associated with these rights.

\section{Take down policy}

The Research Portal is Ulster University's institutional repository that provides access to Ulster's research outputs. Every effort has been made to ensure that content in the Research Portal does not infringe any person's rights, or applicable UK laws. If you discover content in the Research Portal that you believe breaches copyright or violates any law, please contact pure-support@ulster.ac.uk. 


\title{
Valorization of biodiesel side stream waste glycerol for rhamnolipids production by Pseudomonas aeruginosa RS6 ${ }^{2 /}$
}

\author{
Shobanah Menon Baskaran ${ }^{a}$, Mohd Rafein Zakaria a, b, *, \\ Ahmad Syafiq Mukhlis Ahmad Sabri a , Mohd Shamzi Mohamed ${ }^{a}$, Helmi Wasoh ${ }^{\text {a }}$, \\ Maeda Toshinari ${ }^{c}$, Mohd Ali Hassan ${ }^{\mathrm{a}, \mathrm{b}}$, Ibrahim M. Banat ${ }^{\mathrm{d}}$ \\ a Department of Bioprocess Technology, Faculty of Biotechnology and Biomolecular Sciences, Universiti Putra Malaysia, 43400, UPM Serdang, Selangor, \\ Malaysia \\ ${ }^{\mathrm{b}}$ Laboratory of Processing and Product Development, Institute of Plantation Studies, Universiti Putra Malaysia, 43400, UPM Serdang, Selangor, Malaysia \\ ${ }^{\mathrm{c}}$ Department of Biological Functions Engineering, Graduate School of Life Science and Systems Engineering, Kyushu Institute of Technology, 2-4 Hibikino, \\ Wakamatsu-ku, Kitakyushu, 808-0196, Japan \\ d School of Biomedical Sciences, Faculty of Life and Health Sciences, University of Ulster, Coleraine BT52 1SA, Northern Ireland, UK
}

\section{A R T I C L E I N F O}

\section{Article history:}

Received 6 June 2020

Received in revised form

6 February 2021

Accepted 10 February 2021

Available online 13 February 2021

\section{Keywords:}

Valorization

Waste glycerol

Rhamnolipid

$P$. aeruginosa, eco-biomaterial

Green chemicals

\begin{abstract}
A B S T R A C T
Biodiesel side stream waste glycerol was identified as a cheap carbon source for rhamnolipids (RLs) production which at the same time could improve the management of waste. The present study aimed to produce RLs by using Pseudomonas aeruginosa RS6 utilizing waste glycerol as a substrate and to evaluate their physico-chemicals properties. Fermentation conditions such as temperature, initial medium $\mathrm{pH}$, waste glycerol concentration, nitrogen sources and concentrations resulted in different compositions of the mono- and di-RLs produced. The maximum RLs production of $2.73 \mathrm{~g} / \mathrm{L}$ was obtained when $P$. aeruginosa RS6 was grown in a basal salt medium supplemented with $1 \%$ waste glycerol and $0.2 \mathrm{M}$ sodium nitrate at $35^{\circ} \mathrm{C}$ and $\mathrm{pH}$ 6.5. At optimal fermentation conditions, the emulsification index ( $\left.\mathrm{E}_{24}\right)$ values of cooking oil, diesel oil, benzene, olive oil, petroleum, and kerosene were all above $\mathrm{E}_{24=50 \%}$. The surface tension reduction obtained from $72.13 \mathrm{mN} / \mathrm{m}$ to $29.4-30.4 \mathrm{mN} / \mathrm{m}$ was better than the surface activity of some chemical-based surfactants. The RLs produced possessed antimicrobial activities against Gram-negative and Gram-positive bacteria with values ranging from $37 \%$ to $77 \%$ of growth inhibition when $1 \mathrm{mg} / \mathrm{mL}$ of RLs was used. Concentrations of RLs below $1500 \mu \mathrm{g} / \mathrm{mL}$ did not induce phytotoxicity effects on the tested seeds (Vigna radiata) compared to the chemical-based- surfactant, SDS. Furthermore, RLs tested on zebrafish (Danio rerio) embryos only exhibited low acute toxicity with an LC $_{50}$ value of $72.97 \mu \mathrm{g} / \mathrm{mL}$ at $48 \mathrm{~h}$ of exposure suggesting a green and eco-biochemical worthy of future applications to replace chemical-based surfactants.
\end{abstract}

(C) 2021 Elsevier Ltd. All rights reserved.

\section{Introduction}

Surfactants, also known as surface-active agents, are amphipathic compounds consisting of hydrophilic and hydrophobic moieties that give unique properties to these molecules when in different media or phases (Marchant and Banat, 2012a). The surfactants can either be synthetic compounds produced from fossil

\footnotetext{
4 This paper has been recommended for acceptance by Dr. Jörg Rinklebe.

* Corresponding author. Department of Bioprocess Technology, Faculty of Biotechnology and Biomolecular Sciences, Universiti Putra Malaysia, 43400, UPM Serdang, Selangor, Malaysia.

E-mail address: mohdrafein@upm.edu.my (M.R. Zakaria).
}

fuels which are petroleum, natural gas, or coal, all types of nonrenewable resources or natural surfactants derived from biological sources such as microbes, animals or plants (Gudiña et al., 2015). Due to the mass usage of surfactants in both households and industries, large quantities of used surfactants are discharged into the sewage system or straight into surface water bodies such as rivers, lakes or oceans. High surfactants levels in the environment can substantially affect the ecosystem as they are mostly toxic to all ranges of organisms (Lima et al., 2011). Thus, to overcome such negative environmental impacts caused by the discharge of synthetic surfactants and to preserve a good quality environment for our future generations, synthetic surfactants must be replaced by biodegradable alternatives wherever possible. 
Biosurfactants are the possible environmentally friendly alternatives over synthetic surfactants (Gudiña et al., 2015). Microbially derived surfactants have more advantages when compared to plant-derived ones due to their capacities for scale-up production, useful multifunctional properties and rapid production by fastgrowing microorganisms (Randhawa and Rahman, 2014). Interest in biosurfactants has been steadily increasing because of the limitations of synthetic surfactants which are toxic, of low biodegradability and limited effectiveness in a narrow range of $\mathrm{pH}$ and temperature (Suryanti et al., 2009). Biosurfactants are classified according to their chemical compositions either as glycolipids, lipopeptides, lipopolysaccharides, and oligosaccharides (Marchant and Banat, 2012b). Based on their microbial origins, Pseudomonas sp. are known for their capacities to produce rhamnolipids. Bacillus subtilis and other bacilli are known to produce lipopeptide biosurfactants whereas sophorolipids are produced by Candida sp., which belongs to the yeast group (Silva et al., 2014). One of the most promising types of biosurfactants to replace current nonbiodegradable surfactants is RLs produced by Pseudomonas species (Pereira et al., 2013).

Pseudomonas aeruginosa is a rod-shaped, Gram-negative, facultative anaerobic and mono-flagellated bacterium is a Biosafety-Level 2 pathogen. This bacterium can be isolated from various habitats including soil, water and plants. The size of its rodshaped cell is about $0.5-0.8 \mu \mathrm{m}$ by $1.5-3.0 \mu \mathrm{m}$ in terms of its length and width (Sarabhai et al., 2016). P. aeruginosa rarely causes infections in healthy individuals, but it is a major threat to patients with malignancies or HIV infection, patients who are mechanically ventilated, patients, and individuals who are immunocompromised (Sadikot et al., 2015). P. aeruginosa generates an amazing array for both cell-associated and extracellular virulence factor to facilitate the establishment of infection (Wahdan et al., 2020). Numerous molecular methods to determine species level of Pseudomonas sp. using specific primers targeting oprL gene (Matthijs et al., 2013), verification of virulence of $P$. aeruginosa strains using specific primers targeting the toxA and exoS virulence genes (Matar et al., 2002; Strateva, 2008) are reported. A number of these virulence factors are regulated by quorum sensing (QS). QS is the mechanism by which an individual bacterium produces small diffusible molecules that surrounding organisms can detect (Smith and Iglewski, 2003). There are currently a variety of different approaches under investigation that either includes finding an alternative (nonpathogenic) source of RLs for commercial use or genetically modifying a non-pathogenic organism to synthesize RLs. But the RLs yields obtained were significantly lower than those of $P$. aeruginosa wild-type strains (Twigg et al., 2018).

Waste glycerol represents about $10 \%(w t)$ of the initial raw material in the biodiesel production industry (Chi et al., 2007). Waste glycerol production has been increasing rapidly due to the demand for biodiesel production, leading to a large amount of waste glycerol being generated (Bharali et al., 2014). However, the technologies for the purification of waste glycerol are scarce and not economically viable (Vivek et al., 2017). Biotransformation of waste glycerol into value-added chemicals is under development, and the focus is more on the sustainability of by-product production and waste management in integrated biorefineries (Vivek et al., 2017). Biodiesel from waste cooking oil had been produced in a pilot-scale reactor (Farid et al., 2017) with consequently large quantities of continuously produced waste glycerol leading to storage issues. Nowadays, most biotechnological processes involve the use of glycerol as a raw substrate. Hence, the utilization of a byproduct from the biodiesel industry, crude glycerine, able to provide an option to minimize the cost of production (Pereira et al., 2013). Waste glycerine is used successfully for various microbial productions as a water-soluble carbon source (Eraqi et al., 2016). For example, anaerobic glycerol fermentation by E. coli produces a mixture of products like ethanol, acetate, succinate, hydrogen and lactate (Dharmadi et al., 2006). Glycerine can also be used to manufacture various products such as 1,3 propanediol (GonzálezPajuelo et al., 2006), lipid (Narayan et al., 2005; Papanikolaou and Aggelis, 2002), and pigment (Narayan et al., 2005) by it being a carbon source in fermentation processes.

The present work, therefore, aimed to investigate the suitability of using biodiesel side stream waste glycerol for RLs production by the newly isolated $P$. aeruginosa RS6 as an alternative in waste management and sustainable by-product generation. The effects of fermentation conditions such as temperature, initial medium $\mathrm{pH}$, concentration of waste glycerol, nitrogen sources and their concentrations were investigated to achieve optimal RLs production. The successful biotransformation reaction of waste glycerol by $P$. aeruginosa RS6 was evaluated in terms of the emulsification index, RLs yields, and other indicative properties of the biosurfactants produced. Phytotoxicity, antimicrobial as well as the ecotoxicological properties of the RLs produced were also investigated.

\section{Materials and methods}

\subsection{Waste glycerol treatment}

The waste glycerol used in the present work was obtained from the biodiesel pilot-plant operated at the Biomass Technology Centre, Universiti Putra Malaysia (UPM), Malaysia. The biodiesel was produced from waste cooking oil according to the method published by Farid et al. (2017). Impurities were removed whereby the suspended solids were first removed using a sieve after the waste glycerol was treated with concentrated $\mathrm{H}_{2} \mathrm{SO}_{4}$ and heated for $1 \mathrm{~h}$ to remove methanol and water. The material was then centrifuged at $3000 \mathrm{rpm}$ for $10 \mathrm{~min}$, and the supernatant was used as a substrate for the rhamnolipid production (Kondo et al., 2015).

\subsection{Preparation of Pseudomonas aeruginosa RS6}

Pseudomonas aeruginosa RS6 was obtained from the Institute of Bioscience, UPM, and stored as a glycerol stock at $-80{ }^{\circ} \mathrm{C}$. The $P$. aeruginosa RS6 strain originally isolated from the Sri Serdang Lake, Selangor, Malaysia, biochemically characterised and had the potential to produce biosurfactants (Nordin et al., 2013). $P$. aeruginosa RS6 was streaked onto a nutrient agar plate and incubated at $37{ }^{\circ} \mathrm{C}$ for $24 \mathrm{~h}$. For the preparation of seed culture, a single colony of $P$. aeruginosa RS6 was cultured into a sterile test tube containing $5 \mathrm{~mL}$ of nutrient broth and incubated at $30^{\circ} \mathrm{C}$, $180 \mathrm{rpm}$ for $15-16 \mathrm{~h}$. Growth was observed by measuring the optical density (OD) of the culture broth. Inoculum preparation was carried out using $5 \mathrm{~mL}$ of seed culture transferred into a $250 \mathrm{~mL}$ shake flask containing $45 \mathrm{~mL}$ of nutrient broth and incubated at $30{ }^{\circ} \mathrm{C}$, agitated at $180 \mathrm{rpm}$ for $15-16 \mathrm{~h}$ (Nordin et al., 2013).

\subsection{Medium and fermentation conditions for rhamnolipids production}

About $10 \%(\mathrm{v} / \mathrm{v})$ inoculum was inoculated into freshly prepared basal salt media (BSM) according to the formulation proposed by Zhang et al. (2012). The BSM was autoclaved at $121^{\circ} \mathrm{C}$ for $20 \mathrm{~min}$ separately from the carbon source, waste glycerol. For the optimization study, $P$. aeruginosa RS6 was incubated at a different temperature, initial medium $\mathrm{pH}$, concentrations of carbon sources, nitrogen sources, and nitrogen concentrations of the chosen nitrogen source for $72 \mathrm{~h}$. 


\subsection{Optimization of rhamnolipids production}

Temperature. Four different temperatures; $25^{\circ} \mathrm{C}, 30^{\circ} \mathrm{C}, 35^{\circ} \mathrm{C}$, and $37{ }^{\circ} \mathrm{C}$ were tested to determine the effects of temperature on RLs production. The initial $\mathrm{pH}$ of the BSM was adjusted to $\mathrm{pH} 7.0$ by adding either $1 \mathrm{M} \mathrm{NaOH}$ or $1 \mathrm{M} \mathrm{HCl}$ and autoclaved at $121{ }^{\circ} \mathrm{C}$ for 20 min separately from the carbon source, waste glycerol. Then, the $250 \mathrm{~mL}$ shake flask containing fresh BSM was inoculated with $10 \%$ $(\mathrm{v} / \mathrm{v})$ inoculum and $1 \%(\mathrm{v} / \mathrm{v})$ waste glycerol with a working volume of $50 \mathrm{~mL}$ and incubated for $72 \mathrm{~h}$ at a selected temperature and agitated at $180 \mathrm{rpm}$.

Initial medium $\mathrm{pH}$. The cultures were incubated at different initial medium $\mathrm{pH}$ values; $6.0,6.5,7.0$, and 7.5 to determine the optimum initial medium $\mathrm{pH}$ for the RLs production. The initial $\mathrm{pH}$ of the BSM was adjusted by adding either $1 \mathrm{M} \mathrm{NaOH}$ or $1 \mathrm{M} \mathrm{HCl}$.

Concentrations of waste glycerol. The cultures were supplemented with different concentrations of waste glycerol (v/v); $1.0 \%$, $1.5 \%, 2.0 \%$, and $2.5 \%$ to monitor the effects of substrate concentrations on RLs production.

Nitrogen sources. The cultures were supplemented with different sources of nitrogen at a concentration of $0.02 \mathrm{M}$. Sodium nitrate $\left(\mathrm{NaNO}_{3}\right)$, potassium nitrate $\left(\mathrm{KNO}_{3}\right)$, ammonium chloride $\left(\mathrm{NH}_{4} \mathrm{Cl}\right)$ and ammonium nitrate $\left(\mathrm{NH}_{4} \mathrm{NO}_{3}\right)$ were each used to replace the $\mathrm{NaNO}_{3}$ in the BSM in the experiments to test different sources of nitrogen.

Concentrations of nitrogen source. The cultures were incubated in BSM containing the best nitrogen source at different concentration of $0.02,0.05,0.1$, and $0.2 \mathrm{M}$ to study the effects of concentrations of nitrogen in the production of RLs.

The selection of the fermentation parameters mentioned above was based on a study reported earlier (Saikia et al., 2012). The Tukey Honestly Significant Difference (HSD) function of the SAS (version 9) software was used to compare the means of RLs concentrations and the emulsification index.

\subsection{Analyses}

\subsubsection{Determination of optical cell density}

The cell OD was used to measure the cell mass indirectly. The cell OD was determined using a spectrophotometer (Thermo Fischer Scientific, USA) at wavelength $600 \mathrm{~nm}$.

\subsubsection{Determination of glycerol and fatty acid methyl ester compositions}

Based on the method proposed by (Sluiter et al., 2006) with modifications, the glycerol concentration was determined by using a HPLC equipped with a refractive index detector and an ion exchange Aminex HPX-87H column $(300 \times 7.8 \mathrm{~mm})$ with $0.005 \mathrm{M}$ sulphuric acid $\left(\mathrm{H}_{2} \mathrm{SO}_{4}\right)$ as a mobile phase. The mobile phase was filtered using a $0.22 \mu \mathrm{m}$ nylon membrane filter (Millipore, USA) and degassed using a sonicator. The analysis was carried out under the following conditions; flow rate of $0.6 \mathrm{~mL} / \mathrm{min}$ at $60{ }^{\circ} \mathrm{C}$, and the volume of injection was in the range $10-25 \mu \mathrm{L}$. The supernatants were filtered before analysis using a $0.22 \mu \mathrm{m}$ cellulose-acetate filter. The glycerol concentration was measured using the standard curve of glycerol prepared earlier in the range of between $0.2 \mathrm{mg} / \mathrm{mL}$ to $8.0 \mathrm{mg} / \mathrm{mL}$.

Samples of waste glycerol were sent to the Faculty of Food Science and Technology, UPM for analysis of fatty acid methyl ester (FAME) using gas chromatography with flame ionization detector (GC-FID) to determine the fatty acid composition.

\subsubsection{Determination of protein concentration}

The protein concentration was determined using the Bradford assay (Bradford, 1976). According to Smyth et al. (2010), the binding of Coomassie Brilliant Blue with protein gives a colour change, which can be quantified using a spectrophotometer.

\subsubsection{Determination of rhamnolipid concentration}

The rhamnolipids produced were determined according to the HPLC-UV method proposed by Smyth et al. (2010). The HPLC was equipped with a HPLC column (C18 column $250 \mathrm{~mm} \times 4.6 \mathrm{~mm} \times 5 \mu \mathrm{m}$ i.d.) and a UV detection set at $244 \mathrm{~nm}$. The flow rate was set at $1.0 \mathrm{~mL} / \mathrm{min}$ with an injection volume of $20 \mu \mathrm{L}$. Then, $1 \mathrm{~mL}$ of acetonitrile containing 2-bromoacetophenone and trimethylamine was added into $1 \mathrm{~mL}$ of cell-free supernatant with a molar ratio of 1:4:2 (glycolipid: 2-bromoacetophenone: $\mathrm{Et}_{3} \mathrm{~N}$ ). The samples were heated for $1 \mathrm{~h}$ at $80^{\circ} \mathrm{C}$ and filtered through a $0.22 \mu \mathrm{m}$ syringe filter to remove particulate material. The mobile phase used was $\mathrm{A}\left(\mathrm{CH}_{3} \mathrm{CN}\right)$ and $\mathrm{B}\left(3.3 \mathrm{mM} \mathrm{H}_{3} \mathrm{PO}_{4}\right)$. The gradient conditions were set as $50 \% \mathrm{~A}$ and $50 \% \mathrm{~B}$ for $3 \mathrm{~min}$, then to $100 \%$ mobile phase A over $19 \mathrm{~min}$ and held for $5 \mathrm{~min}$, followed by a change to $50 \%$ A over $3 \mathrm{~min}$ and held for $10 \mathrm{~min}$. The rhamnolipid concentration was measured using the standard curve of rhamnolipid prepared earlier in the range of between $0.2 \mathrm{mg} / \mathrm{mL}$ to $1.0 \mathrm{mg} / \mathrm{mL}$.

\subsubsection{Quantitative emulsification index (E24)}

The emulsification index was measured to determine the capacity of emulsion formation by the RLs produced by P. aeruginosa RS6. The fermentation broth was centrifuged at $10,000 \mathrm{rpm}$ for $30 \mathrm{~min}$ at $4{ }^{\circ} \mathrm{C}$, and the cell pellets were removed. Then, $2 \mathrm{~mL}$ of the supernatant was added into $2 \mathrm{~mL}$ of the hydrophobic substrate such as cooking oil and diesel oil in a test tube. The mixture was mixed thoroughly by vortexing for $2 \mathrm{~min}$. Then, the mixture was left for $24 \mathrm{~h}$ to react. According to Aparna et al. (2012), the $\mathrm{E}_{24}$ was calculated as a percentage of the height of the emulsion layer over a total height of mixture as expressed in equation (1) below:

$$
\text { Emulsion Index }\left(E_{24}\right)=\frac{\text { The height of the emulsion layer }}{\text { The total height of the mixture }} \times 100
$$

As for the thermal stability tests, the supernatant containing RLs was autoclaved at $110{ }^{\circ} \mathrm{C}$ for $15 \mathrm{~min}$ to determine the thermal stability of the RLs (Reddy et al., 2016). For the comparative study, a synthetic surfactant such as SDS, Triton X-100, and Tween 80 was used as a positive control. SDS was selected to represent the anionic surfactants while Triton X-100 and Tween 80 represented the nonionic surfactants.

\subsubsection{Surface tension measurement}

The surface tension of the cell-free supernatant containing RLs from $P$. aeruginosa RS6 was measured using an automated surface tensiometer (Kibron Inc., Finland). The measurement of surface tension was based on the Du Nouy ring or maximum pull force method which utilized the interaction between the platinum ring and the surface of the liquid except that this automated surface tensiometer used a small needle-like probe instead of a ring (Rooney et al., 2009). The Dyne cup containing the sample was placed on the measurement tray. The needle probe was sterilized with flame each time before measuring the surface tension of the sample. The tensiometer was calibrated with distilled water before use.

\subsubsection{Liquid chromatography-mass spectrometry (LC-MS)}

The solid-phase extraction purified RLs were dissolved in methanol and subjected to LC-MS characterization using an Accela LC system (Thermo, San Jose, CA, USA). The Finnegan TSQ Quantum Ultra mass (Thermo Scientific, CA, USA) system consisted of a 
binary pump, a degasser, a column oven and an autosampler. The analysis was done on a C18 column, $50 \times 2.1 \mathrm{~mm}$ i.d., $1.9 \mathrm{~mm}$ particle size (Thermo Scientific, CA, USA). The column temperature was kept at $40{ }^{\circ} \mathrm{C}$. The flow rate was set to $0.3 \mathrm{~mL} / \mathrm{min}$. A mobile phase gradient consisting of water (A) and methanol (v/v) (B) was used. The gradient was set to $5 \%$ B from 0 to 6 min, increased to $95 \%$ B from 6 to $10 \mathrm{~min}$ and remained constant for $4 \mathrm{~min}$ at $95 \% \mathrm{~B}$ before it was decreased to $5 \%$ in $5 \mathrm{~min}$ and remained constant for equilibration. The total run time was $15 \mathrm{~min}$. The injection volume was $5 \mu \mathrm{L}$. Mass spectrometry was performed in the ESI-positive mode using the MS (full scan) experiment for rhamnolipid identification. The optimal values for the ESI source parameters were determined with a rhamnolipid solution for the ESI-positive mode. Full scan data were obtained by scanning from m/z 0 to 1000 (Gudiña et al., 2015).

\subsubsection{Fourier transform infrared (FT-IR) spectroscopy analysis}

The spectra of RLs were characterized by a Nicolet iS5 spectrometer with an iD1 Transmission adapter (Thermo Scientific, Waltham, MA). FT-IR spectra were recorded in wavenumbers ranging from 4000 to $400 \mathrm{~cm}^{-1}$ using 16 scans.

\subsubsection{Determination of antimicrobial activity}

The antimicrobial activities of RLs against four different pathogenic microbial strains, B. pumilus, E. mallotivora, P. stewartii, and $P$. ananatis were determined by using the microdilution method utilizing 96-well flat-bottom microdilution plates as previously described by Luna et al. (2011) with some modifications. These pathogen strains were selected due to their being available in the laboratory. These strains are the common pathogens infecting papaya, paddy, mango and maize which are important crops in Malaysia. The bacterial inoculum was prepared by culturing all the strains individually in nutrient broth (NB) and further incubation overnight at $30^{\circ} \mathrm{C}$ on a rotary shaker at $180 \mathrm{rpm}$. Briefly, $125 \mu \mathrm{L}$ of sterile nutrient broth was dispensed into all the wells of 96-well microdilution plates. Subsequently, $125 \mu \mathrm{L}$ of purified rhamnolipid solution at a concentration of $2 \mathrm{mg} / \mathrm{mL}$ was added to the first column and mixed with the medium to attain the final concentration of $1 \mathrm{mg} / \mathrm{mL}$. Then, $125 \mu \mathrm{L}$ from the first column was transferred serially to the subsequent wells to meet appropriate concentration. The microplates were incubated at $37{ }^{\circ} \mathrm{C}$ for $24 \mathrm{~h}$. The assay was performed in triplicates at all rhamnolipid concentrations for each strain. Bacterial growth was monitored by absorbance at $600 \mathrm{~nm}$ for each well using a microplate reader. The percentages of growth inhibition at different biosurfactant concentrations for each strain were calculated as in equation (2);

$\%$ Growth inhibitions $=[1-($ Ac $/$ Ao $)] \times 100$

where Ac is the absorbance of the column with a biosurfactant concentration (c) and Ao is the absorbance of growth control (NB + tested culture).

\subsubsection{Phytotoxicity assay}

In a static test, seed germination and root elongation of green gram (Vigna radiata) were determined for phytotoxicity of the extracted RLs according to the methods described earlier with some modifications (Tiquia et al., 1996). Solutions of RLs were prepared with deionized water at concentrations of 100, 300, 500, 1000 , and $1500 \mu \mathrm{g} / \mathrm{mL}$. The seeds were pre-sterilized with $2 \%$ sodium hypochlorite $(\mathrm{NaOCl})$ for $5 \mathrm{~min}$ and subsequently washed thoroughly with distilled water. Ten seeds were inoculated in each sterilized Petri dish containing Whatman filter paper which had been moistened with $5 \mathrm{~mL}$ of RLs solution at room temperature. The seeds inoculated were considered germinated when the radicle tip grew out of the seed coat. The seed germination, root elongation $(\geq 0.5 \mathrm{~cm})$ and germination index (GI) after five days of incubation in the dark were evaluated as shown in equations (3)-(5):

Relative seed germination $(\%)=$

number of seeds germinated in the extract

number of seeds germinated in control $x 100$

Relative root length $(\%)=\frac{\text { mean root length in the extract }}{\text { mean root length in the control }} \times 100$

Germination index $=\frac{(\% \text { of seed germination }) x(\% \text { of root growth })}{100 \%}$

Distilled water was used as a control in this assay. The mean and standard deviation of triplicate samples from different concentrations were calculated.

\subsubsection{Zebrafish toxicity assay}

The fish embryo toxicity test using zebrafish was performed according to the protocol described by Hogan et al. (2019) with some modifications to investigate the possible toxicity of RLS. Zebrafish embryos with intact chorions were exposed to the RLs from $24 \mathrm{~h}$ to $120 \mathrm{~h}$ post-exposure (hpe). Briefly, at $24 \mathrm{~h}$ postfertilization (hpf), the embryos were transferred manually using a transfer pipette into a 96-well plate containing embryo medium $(100 \mu \mathrm{L})$ consisting of $0.2 \%$ Dimethyl sulfoxide (DMSO). Rhamnolipid solutions were prepared in another 96-well plate by making a two-fold serial dilution resulting in concentrations ranging from $15.63 \mu \mathrm{g} / \mathrm{mL}$ to $1000 \mu \mathrm{g} / \mathrm{mL}$. Then, $100 \mu \mathrm{L}$ of RLs solutions were added into the embryo plate, and 12 replicates were run for each concentration and control (embryo media with $0.2 \%$ DMSO). Later, the embryo plate covered with lid was incubated at $28{ }^{\circ} \mathrm{C}$. The zebrafish embryos were observed every $24 \mathrm{~h}$ until $120 \mathrm{~h}$ of exposure under an inverted microscope. The treated zebrafish embryos were evaluated for lethal effects and malformations (coagulation of embryos, non-hatching, and no somite formation).

\section{Results and discussion}

\subsection{Waste glycerol}

Crude glycerol from biodiesel production typically composed of an aqueous fraction of glycerol, methanol, water and an organic fraction which consisted of glycerides, free fatty acids, and FAMEs (Farid et al., 2017). In this study, the composition of FAME was identified using GC-FID. As shown in Table 1, the major fatty acids present in waste glycerol were oleic acid and palmitic acid at $44.8 \%$ and $39.8 \%$, respectively. The chemical composition of biodieselderived glycerol varied depending on the methods and raw materials used (Yang et al., 2012). The major fatty acids reported in waste cooking oil were palmitic acid and oleic acid in the range from 41 to $47 \%$ and $38.2-43.5 \%$, respectively (Supardan et al., 2017). The waste glycerol was subjected to removal of the solid component, methanol, and water. There was a substantial visual difference between treated waste glycerol (TWG) and non-treated waste glycerol (NTWG) whereby the treated waste glycerol was clear and free from impurities (Fig. S1). The impurities in the waste glycerol included fatty acids, methanol, salts, soaps, and heavy metals (Chatzifragkou and Papanikolaou, 2012). The concentration of 
Table 1

The chemical properties of waste glycerol used in the present study.

\begin{tabular}{ll}
\hline Chemical properties & Values \\
\hline $\mathrm{pH}$ & 9.20 \\
Glycerol in NTWG & $31.94 \mathrm{~g} / \mathrm{L}$ \\
Glycerol in TWG & $23.03 \mathrm{~g} / \mathrm{L}$ \\
Fatty acids (\%) & \\
Lauric acid (C12:0) & 0.40 \\
Myristic acid (C14:0) & 1.10 \\
Palmitic acid (C16:0) & 39.80 \\
Palmitoleic acid (C16:1) & 0.70 \\
Stearic acid (C18:0) & 4.50 \\
Oleic acid (C18:1, cis) & 44.80 \\
Linoleic acid (C18:2, cis) & 8.70 \\
\hline
\end{tabular}

Values presented are means of duplicate analyses.

glycerol in TWG was further quantified using HPLC. The concentrations of glycerol obtained from TWG and NTWG by HPLC were $23 \mathrm{~g} / \mathrm{L}$ and $30 \mathrm{~g} / \mathrm{L}$, respectively (Table 1).

\subsection{Optimization of rhamnolipid production}

\subsubsection{Temperature}

The cultures were incubated at four different temperatures, $25{ }^{\circ} \mathrm{C}, 30{ }^{\circ} \mathrm{C}, 35{ }^{\circ} \mathrm{C}$ and $37{ }^{\circ} \mathrm{C}$ at $180 \mathrm{rpm}$ for $72 \mathrm{~h}$. Pseudomonas aeruginosa RS6 grew well at selected temperatures and the highest RLs produced was at $35{ }^{\circ} \mathrm{C}$ with a concentration of $1.78 \mathrm{~g} / \mathrm{L}$. The composition of mono- RLs was greater than di- RLs except when grown at $37{ }^{\circ} \mathrm{C}$ (Fig. 1a). The emulsification index was measured and used to determine the capacity of emulsion formation as an indirect measurement of the RLs produced by P. aeruginosa RS6. Based on the emulsification index (Fig. 2a), the optimum temperature to produce RLs was at $35^{\circ} \mathrm{C}$ with $\mathrm{E}_{24}$ values of $60 \%$ on diesel and $43.95 \%$ on cooking oil. The $\mathrm{E}_{24}$ of RLs produced at $25^{\circ} \mathrm{C}(34.44 \%$ on diesel oil and $21.53 \%$ on cooking oil) was the lowest. A study by Wei et al. (2005) found that the optimum temperature for RLs production was between $30{ }^{\circ} \mathrm{C}$ and $37^{\circ} \mathrm{C}$. The emulsification activity by the RLs produced at $35^{\circ} \mathrm{C}$ was competitive with SDS as it emulsified cooking oil and diesel oil by $43.95 \%$ and $60 \%$, respectively while SDS emulsified cooking oil and diesel oil by $56.67 \%$ and $63.33 \%$, respectively.

\subsubsection{Initial medium $p H$}

Growth and RLs production were also influenced by the initial medium $\mathrm{pH}$ tested. The highest growth was achieved when $P$. aeruginosa RS6 was grown at neutral $\mathrm{pH}$. The highest RLs production, $1.98 \mathrm{~g} / \mathrm{L}$, was obtained when the initial medium $\mathrm{pH}$ was 6.0 , and di-RLs production showed a decreasing trend towards alkaline $\mathrm{pH}$ (Fig. 1b). The emulsification index of the RLs produced for all $\mathrm{pH}$ values was almost similar but registered the best result in $\mathrm{pH} 6.5$ with $\mathrm{E}_{24}$ values of $58.94 \%$ and $61.67 \%$ on diesel oil and cooking oil, respectively (Fig. 2b). However, at pH 7.5, the $\mathrm{E}_{24}$ values were slightly lower than at the others, $58.06 \%$ for diesel oil, and $57.75 \%$ for cooking oil. Chen et al. (2007) reported that as pH was controlled at conditions lower than 6.5 or higher than 7.5, the RLs production decreased accordingly. Thus, it could be inferred that $P$. aeruginosa RS6 produced RLs effectively under neutral conditions. The current results suggested that the RLs produced were of high quality and comparable with synthetic surfactants as the $E_{24}$ values on diesel oil and cooking oil were $63.33 \%$ and $56.67 \%$, respectively.

\subsubsection{The concentration of waste glycerol}

Pereira et al. (2013) found that P. aeruginosa PA1 was able to grow in MSM supplemented with crude glycerol in concentrations from 40 to $67 \mathrm{~g} / \mathrm{L}$. Approximately $2.75 \mathrm{~g} / \mathrm{L}$ of RLs was produced from $50 \mathrm{~g} / \mathrm{L}$ of crude glycerol used. In this study, the cultures were incubated in four different concentrations of waste glycerol; $1 \%$, $1.5 \%, 2 \%$ and $2.5 \%$ at $35{ }^{\circ} \mathrm{C}$ with an agitation speed of $180 \mathrm{rpm}$. The growth and production of RLs were correlated well with the amount of substrates in the BSM. The highest RLs production was $2.11 \mathrm{~g} / \mathrm{L}$ with mono-RLs and di-RLs concentrations of $1.38 \mathrm{~g} / \mathrm{L}$ and $0.73 \mathrm{~g} / \mathrm{L}$, respectively, when $2.5 \%$ of waste glycerol was supplemented in the fermentation medium. The amount of di-RLs components increased concomitantly with higher amounts of waste glycerol added (Fig. 1c). Even though the concentration of RLs increased as the glycerol concentration increased, however, the $\mathrm{E}_{24}$ of the samples decreased as the concentration increased. The highest $\mathrm{E}_{24}$ values of $60.86 \%$ and $50.04 \%$ were obtained from diesel oil and cooking oil, respectively, for samples that had $1 \%$ of waste glycerol supplemented in BSM (Fig. 2c).

\subsubsection{Nitrogen sources}

The effects of different nitrogen sources were observed on the growth and production of RLs. Both ammonium nitrate and ammonium chloride supported the best growth for $P$. aeruginosa RS6. Therefore, lower RLs were produced compared to the other nitrogen sources, i.e., sodium nitrate and potassium nitrate, which produced $1.78 \mathrm{~g} / \mathrm{L}$ and $1.79 \mathrm{~g} / \mathrm{L}$, respectively (Fig. 1d). As shown in Fig. 2d, the optimum nitrogen source to produce RLs in BSM was sodium nitrate, registering the highest $E_{24}$ in both diesel oil and cooking oil with $59.78 \%$ on diesel oil and $33.33 \%$ on cooking oil, respectively. The highest $\mathrm{E}_{24}$ value obtained was in correlation with the high concentration of RLs produced (Fig. 1d). Moussa et al. (2014) reported that sodium nitrate was the best nitrogen source to produce RLs by P. aeruginosa. About $2.3 \mathrm{~g} / \mathrm{L}$ of RLs was produced from $2 \%$ glycerol supplemented with $\mathrm{NaNO}_{3}$ as a source of nitrogen (Wei et al., 2005). The quality of the RLs produced was comparable to that of the synthetic surfactant, SDS. The $E_{24}$ recorded for SDS was $63 \%$ on diesel oil and $56.67 \%$ on cooking oil, respectively.

\subsubsection{Nitrogen concentrations}

The concentrations of sodium nitrate tested were $0.02,0.05$, 0.10 , and $0.20 \mathrm{M}$. The cultures were incubated at $35^{\circ} \mathrm{C}, 180 \mathrm{rpm}$ for $72 \mathrm{~h}$. The growth and production of RLs by P. aeruginosa RS6 correlated with the concentrations of sodium nitrate added in the $\mathrm{BSM}$. The highest RLs were produced at $2.72 \mathrm{~g} / \mathrm{L}$ in conjunction with $0.2 \mathrm{M}$ of sodium nitrate addition to the fermentation medium (Fig. 1e). It was observed that the mono-RLs contents exhibited an increasing trend with a higher concentration of nitrogen source. In contrast, it was an inverse trend in the case of the di-RLs contents. At $0.2 \mathrm{M}$ sodium nitrate, the highest $\mathrm{E}_{24}$ values on both diesel oil and cooking oil were obtained at $60.65 \%$ and $57 \%$, respectively (Fig. 2e). Concentrations of sodium nitrate that were lower than $0.20 \mathrm{M}$ all showed consistent emulsification index, $\mathrm{E}_{24}(>55 \%)$ on diesel oil, and very low values on cooking oil $(<10 \%)$. There are approximately 60 or more rhamnolipids congeners and homologs produced by different species of Pseudomonas and by other microorganisms belonging to other families, classes or even phyla at different concentrations (Abdel-Mawgoud et al., 2010). Even with minor changes in the compositions of the congeners, the physicochemical properties of the rhamnolipids can be significantly affected (Chong and $\mathrm{Li}, 2017$ ). The dominance of rhamnolipid congeners influenced by the carbon substrate, bacterial strain used, age of culture and culture conditions (Bharali and Konwar, 2011). According to Chayabutra et al. (2001), the production of RLs by a $P$. aeruginosa strain increased under nitrogen limiting conditions. In contrast, this study showed that as the concentration of sodium nitrate in the BSM increased from 0.02 to $0.2 \mathrm{M}$, the concentration 

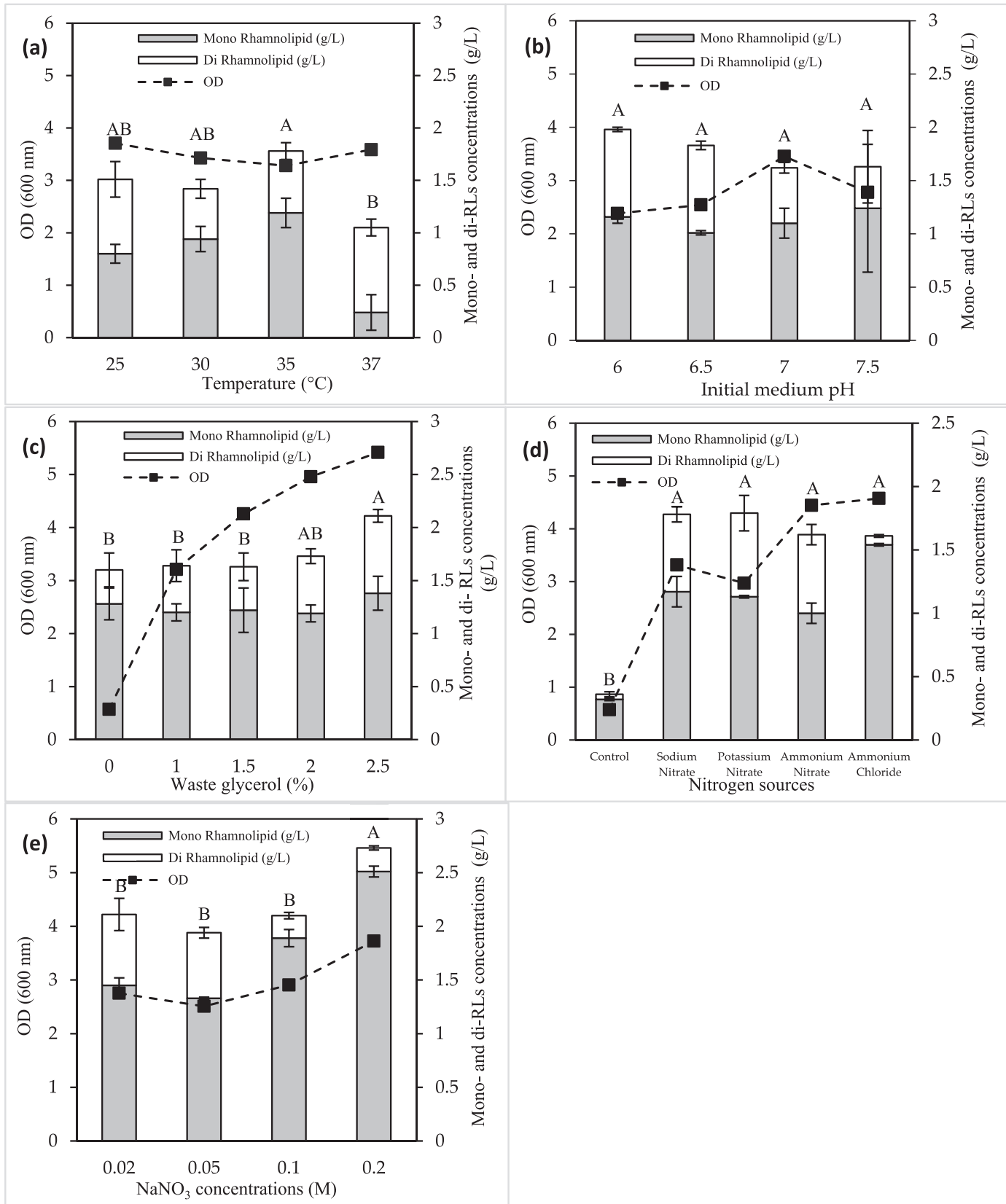

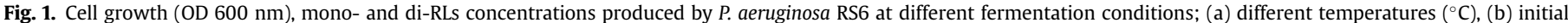

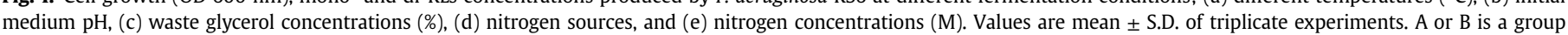
divided by Tukey HSD tests. The means in the same group are not significantly different by the test at $\mathrm{p}<0.05$.

of RLs increased as well. The present work was in agreement with a study performed by Ismail et al. (2015) who reported that the reductions of inorganic iron and nitrogen contents in the growth medium did not affect the production of RLs.

\subsection{Analysis of growth profiles and rhamnolipids production of} Pseudomonas aeruginosa RS6 under optimum cultivation conditions

\subsubsection{Growth, glycerol consumption and $\mathrm{pH}$ profiles}

Pseudomonas aeruginosa RS6 was subsequently cultivated under optimum cultivation conditions in $1 \mathrm{~L}$ shake flasks to monitor the profiles of growth, glycerol consumption, $\mathrm{pH}$, protein concentration and the production of RLs. The cultures were cultivated in BSM supplemented with $0.2 \mathrm{M}$ sodium nitrate and $1 \%$ waste glycerol with a total working volume of $200 \mathrm{~mL}$ and incubated at $35{ }^{\circ} \mathrm{C}$, $180 \mathrm{rpm}$ for $72 \mathrm{~h}$. A $1 \%$ of non-treated waste glycerol (NTWG), $1 \%$ of technical grade glycerol and a control with no carbon source added were used to compare the production of RLs. The growth profiles of $P$. aeruginosa RS6 cultivated with different carbon sources showed a substantial difference with the highest growth observed at $1 \%$ treated waste glycerol (TWG) with an OD value of 3.70 (Fig. 3a). The lowest growth of $P$. aeruginosa was recorded in both $1 \%$ technical grade glycerol and negative control at 0.64 and 0.57 , respectively. The growth of $P$. aeruginosa RS6 in 1\% NTWG was lower than that in 1\% TWG, which might be due to the presence of impurities (Fig. S1) in the NTWG that affected the growth. For the negative control, the OD was the lowest due to the absence of a carbon source for growth. 

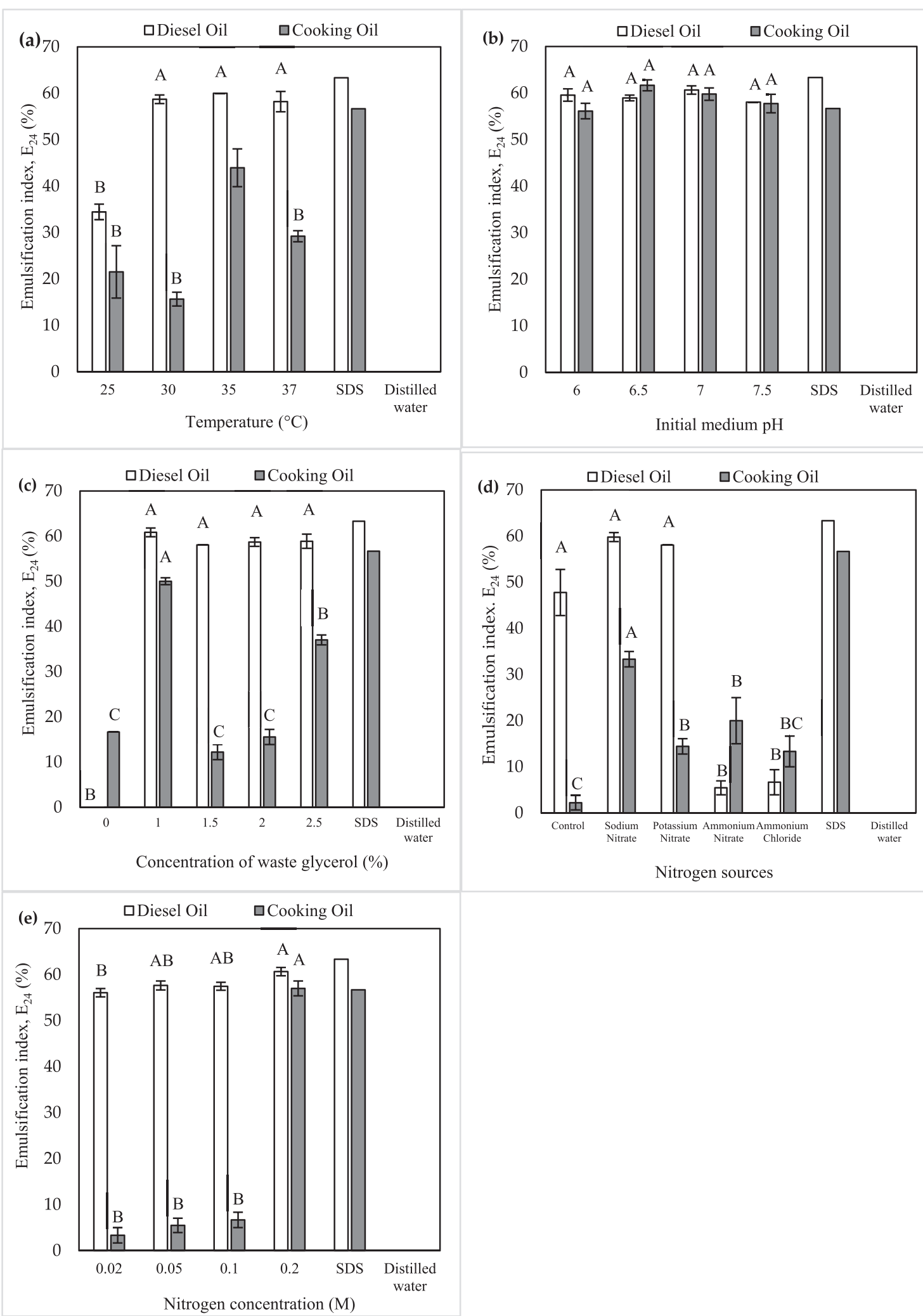

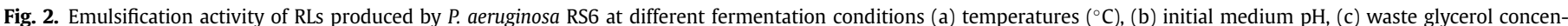

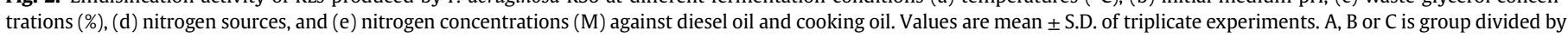
Tukey HSD tests. The means in the same group are not significantly different by the test at $\mathrm{p}<0.05$. 

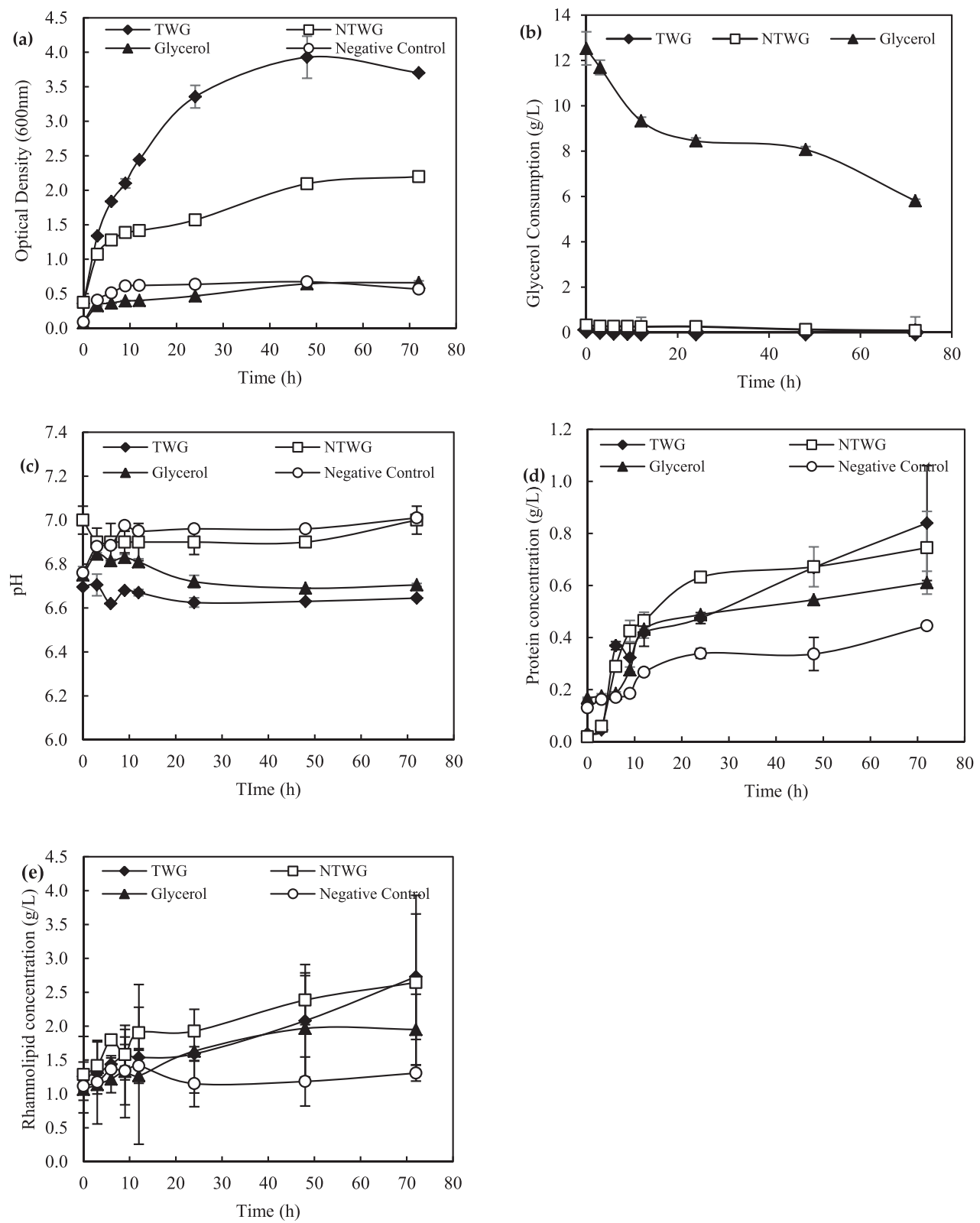

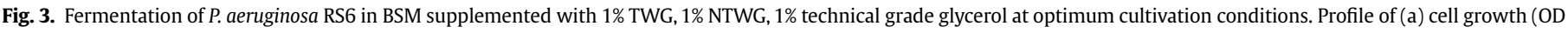
at $600 \mathrm{~nm})$, (b) glycerol consumption $(\mathrm{g} / \mathrm{L}),(\mathrm{c}) \mathrm{pH}$ changes, (d) protein concentration $(\mathrm{g} / \mathrm{L})$ and $(\mathrm{e})$ rhamnolipid $(\mathrm{g} / \mathrm{L})$.

The glycerol consumption pattern for all the carbon sources supplied to $P$. aeruginosa RS6 showed a decreasing trend over time (Fig. 3b). The initial concentrations of the glycerol supplied to BSM as contained in the substrates $1 \%$ TWG, $1 \%$ NTWG, and $1 \%$ technical grade glycerol were $0.11,0.32$, and $12.53 \mathrm{~g} / \mathrm{L}$, respectively. Fig. 3a shows that the OD of $P$. aeruginosa RS6 in 1\% technical grade glycerol was low at 0.64 after $72 \mathrm{~h}$ of incubation. This might be due to the high concentration of glycerol supplied to P. aeruginosa RS6 causing a more viscous aqueous environment to the cell suspension. This in turn affected mass transfer which then decreased the growth of $P$. aeruginosa RS6. Zhu et al. (2013) supported these findings as they reported that bacterial growth was inhibited by high concentrations of glycerol in the growth media which caused osmotic stress on the bacterial cells.

The $\mathrm{pH}$ profiles of the fermentation media during RLs production by $P$. aeruginosa RS6 supplemented with different carbon sources are shown in Fig. 3c. The pH profiles for all the samples were recorded to be in the range from $\mathrm{pH} 6.6$ to $\mathrm{pH}$ 7.0. There was a slight fluctuation observed at $1 \%$ TWG at the early stage of fermentation before it started to stabilize at pH 6.6 after $24 \mathrm{~h}$ of fermentation. For the negative control, the $\mathrm{pH}$ increased from $\mathrm{pH}$ 6.8 to 7 from 0 to $9 \mathrm{~h}$ of fermentation and was maintained at $\mathrm{pH} 7$ after $9 \mathrm{~h}$ of fermentation. Overall, there were no substantial $\mathrm{pH}$ changes observed with the different carbon sources tested. According to Zhu et al. (2012), the optimal pH range for the production of RLs by P. aeruginosa was between 6.0 and 7.2.

The profile of protein concentration and production of RLs by $P$. aeruginosa RS6 in BSM supplemented with different carbon sources were studied (Fig. $3 \mathrm{~d}-\mathrm{e}$ ). The highest protein concentration was recorded when supplemented with $1 \%$ TWG secreting $0.8 \mathrm{~g} / \mathrm{L}$ of protein (Fig. 3d) while the lowest was recorded in the negative control where $P$. aeruginosa RS6 was cultured in BSM 
devoid of carbon source. In general, the profiles of protein concentrations in all carbon sources showed an increasing pattern throughout the fermentation period. The production of protein was in correlation with the amount of RLs produced, as shown in Fig. 3d.

The highest RLs concentration after $72 \mathrm{~h}$ of fermentation was observed at 1\% TWG with $2.73 \mathrm{~g} / \mathrm{L}$, followed by $1 \%$ NTWG, 1\% technical grade glycerol, and negative control (no substrate) with 2.64, 1.95 and $1.31 \mathrm{~g} / \mathrm{L}$, respectively. As for $1 \%$ technical grade glycerol and negative control, the production of RLs started to reach a plateau at the end of the fermentation as this might be due to a factor that limited the production of RLs. Concerning protein concentration, Kronemberger et al. (2008) reported that the stationary protein concentration obtained might be attributed to the presence of proteins other than protease and elastase that were produced and which inhibited the production of RLs. Thus, the production of RLs might be limited by a specific inhibitory protein.

The production of RLs in NTWG was comparable to the RLs produced in TWG even though the growth of $P$. aeruginosa RS6 in BSM supplemented with $1 \%$ NTWG was lower than in $1 \%$ TWG. The higher production of RLs in $1 \%$ NTWG might occur due to the presence of other organic materials such as the residual FAME in it which enhanced the production of RLs. This finding was supported by Ashby et al. (2005) as they found that the use of untreated waste glycerol from biodiesel production enhanced the production of sophorolipid biosurfactants by Candida bombicola where the production was higher than when using pure glycerol. The presence of free fatty acids, fatty acid methyl esters, and other micronutrients in the waste glycerol might enhance the synthesis of biosurfactants.

\subsubsection{Emulsification index test}

The emulsification index $\left(\mathrm{E}_{24}, \mathrm{E}_{4}\right.$, and $\left.\mathrm{E}_{72}\right)$ test was carried out to determine the emulsification stability of the RLs produced by $P$. aeruginosa RS6 using different carbon sources at the optimal cultivation conditions. The emulsification index recorded after $24 \mathrm{~h}$ (Table 2) was labelled as $\mathrm{E}_{24}$, while the emulsification index recorded after $48 \mathrm{~h}$ and $72 \mathrm{~h}$ (Table S1 \& S2) were labelled as $\mathrm{E}_{48}$ and $E_{72}$, respectively. The purpose of performing $E_{48}$ and $E_{72}$ was to determine the stability of emulsion following a longer fermentation period. The samples used were cell-free supernatant of fermentation broth at 24,48 , and $72 \mathrm{~h}$ which were then tested on vegetable oils (cooking oil and olive oil) and hydrocarbons (diesel, benzene, petroleum, and kerosene). The quality of the RLs was then compared with the control, commercial chemical-based surfactants such as SDS, Triton X-100 and Tween 80. SDS was selected to represent anionic surfactant while Triton X-100 and Tween 80 were to represent non-ionic surfactants.

Based on the $E_{24}$ of samples at $72 \mathrm{~h}$ of fermentation (Table 2), RLs produced when supplemented with $1 \%$ technical grade glycerol showed the highest emulsification activity on most of the hydrophobic substrates tested namely 56.45\% (cooking oil), 54.69\% (diesel oil), 50\% (benzene), 53.13\% (olive oil), 53.33\% (petroleum) and $56.45 \%$ (kerosene), and these were followed by 1\% NTWG and $1 \%$ TWG. The emulsification activity of RLs attained from $1 \%$ NTWG was comparable with RLs obtained from $1 \%$ technical grade glycerol. The emulsification activity of RLs from 1\% NTWG was highest on cooking oil, diesel oil, and petroleum with 56.45\%, 58.06\%, and $53.33 \%$, respectively. On the other hand, the RLs produced by P. aeruginosa RS6 from 1\% TWG showed the lowest emulsification activity compared to the other samples. Thus, this indicated that the quality of the rhamnolipid produced by $P$. aeruginosa in $1 \%$ NTWG was better than in $1 \%$ TWG as the $E_{24}$ values were higher in most of the hydrophobic substrates tested.

The $E_{24}$ of samples at $24 \mathrm{~h}$ of fermentation was the lowest due to the low production of RLs at $24 \mathrm{~h}$ of fermentation. Thereafter, the emulsification index started to increase as the fermentation time progressed due to the increase in the production of RLs. The emulsification activity was not necessarily proportional to the concentration of RLs, but the variation in emulsification activity was due to the presence of different RLs homologs in the samples (George and Jayachandran, 2013).

Generally, the emulsification activity for most of the samples reduced from $E_{24}$ to $E_{72}$ at a slow rate. Some RL samples remain unchanged from $E_{24}$ to $E_{72}$. These included RLs produced in $1 \%$ TWG with emulsification activity on kerosene maintained at $53.23 \%$, in $1 \%$ NTWG with emulsification activity on cooking oil and olive oil maintained at $56.45 \%$ and $51.57 \%$, respectively and in $1 \%$ technical grade glycerol with emulsification activity on olive oil maintained at $53.13 \%$. Thus, some RLs produced by $P$. aeruginosa RS6 were able to form stable emulsions even after $72 \mathrm{~h}$ (Table S2).

\subsubsection{Thermal stability test}

The RLs produced after $72 \mathrm{~h}$ of fermentation were autoclaved at $121{ }^{\circ} \mathrm{C}$ for $15 \mathrm{~min}$ and then subjected to an $\mathrm{E}_{24}$ test to study the effect of heat treatment on RLs. In this test, the hydrophobic substrates used were vegetable oil (cooking oil) and hydrocarbons (diesel oil, benzene, and kerosene). Stable emulsification activities were recorded for RLs produced using $1 \%$ TWG, $1 \%$ NTWG, and $1 \%$ technical grade glycerol on all hydrophobic substrates except benzene (Fig. S2). The lowest emulsification activities of the RLs produced were from $1 \%$ TWG, $1 \%$ NTWG, and $1 \%$ technical grade

Table 2

Emulsification activity $\left(\mathrm{E}_{24}\right)$ of rhamnolipid produced by $P$. aeruginosa RS6 using various hydrophobic substrates.

\begin{tabular}{|c|c|c|c|c|c|c|c|}
\hline \multirow[t]{2}{*}{ Sample } & & \multicolumn{6}{|c|}{ Hydrophobic Substrates } \\
\hline & & Cooking Oil & Diesel & Benzene & Olive oil & Petroleum & Kerosene \\
\hline \multirow[t]{3}{*}{$1 \%$ Treated Waste Glycerol } & $24 \mathrm{~h}$ & $0 \pm 0$ & $6.46 \pm 4.56$ & $6.67 \pm 0$ & $3.13 \pm 0$ & $0 \pm 0$ & $27.37 \pm 34.28$ \\
\hline & $48 \mathrm{~h}$ & $50 \pm 0$ & $50 \pm 6.84$ & $8.07 \pm 2.28$ & $51.57 \pm 2.21$ & $6.67 \pm 0$ & $51.61 \pm 9.12$ \\
\hline & $72 \mathrm{~h}$ & $53.23 \pm 2.28$ & $57.21 \pm 5.77$ & $33.34 \pm 23.57$ & $51.57 \pm 2.21$ & $36.67 \pm 23.57$ & $53.23 \pm 2.28$ \\
\hline \multirow[t]{3}{*}{ 1\% Non-treated Waste Glycerol } & $24 \mathrm{~h}$ & $0 \pm 0$ & $29.03 \pm 31.93$ & $7.92 \pm 2.07$ & $1.56 \pm 0$ & $3.33 \pm 0$ & $18.75 \pm 8.84$ \\
\hline & $48 \mathrm{~h}$ & $51.61 \pm 0$ & $54.84 \pm 0$ & $11.29 \pm 2.28$ & $53.13 \pm 0$ & $53.33 \pm 0$ & $54.84 \pm 0$ \\
\hline & $72 \mathrm{~h}$ & $56.45 \pm 2.28$ & $58.06 \pm 0$ & $47.58 \pm 3.42$ & $51.57 \pm 2.21$ & $53.33 \pm 0$ & $51.61 \pm 0$ \\
\hline \multirow[t]{3}{*}{ 1\% Glycerol } & $24 \mathrm{~h}$ & $12.91 \pm 4.56$ & $54.84 \pm 0$ & $29.04 \pm 4.56$ & $51.61 \pm 0$ & $54.95 \pm 2.29$ & $51.61 \pm 0$ \\
\hline & $48 \mathrm{~h}$ & $51.61 \pm 0$ & $54.84 \pm 0$ & $51.61 \pm 0$ & $51.61 \pm 0$ & $52.47 \pm 1.22$ & $54.84 \pm 0$ \\
\hline & $72 \mathrm{~h}$ & $56.45 \pm 2.28$ & $54.69 \pm 0$ & $50 \pm 0$ & $53.13 \pm 0$ & $53.33 \pm 0$ & $56.45 \pm 2.28$ \\
\hline $1 \% \operatorname{SDS}$ & & 53.13 & 52.94 & 59.68 & 54.84 & 56.67 & 56.25 \\
\hline 1\% Tween 80 & & 56.25 & 53.13 & 60 & 54.84 & 53.33 & 59.38 \\
\hline 1\% Triton $\mathrm{x}-100$ & & 58.06 & 56.25 & 6.25 & 54.84 & 58.06 & 56.25 \\
\hline Distilled Water & & 0 & 0 & 0 & 0 & 0 & 0 \\
\hline Negative Control & & 0 & 0 & 0 & 0 & 0 & 0 \\
\hline
\end{tabular}

Results are expressed as the mean \pm standard deviation of three independent readings. 
glycerol which on benzene registered $\mathrm{E}_{24}$ values of $18.62 \%, 13.69 \%$, and $7.07 \%$, respectively. The emulsification activities of the RLs produced from 1\% TWG, $1 \%$ NTWG and $1 \%$ technical grade glycerol on most of the hydrophobic substrates (cooking oil, diesel, and kerosene) were competitive with those of the positive controls $1 \%$ SDS, $1 \%$ Tween 80 and 1\% Triton X-100 (Fig. S2).

This showed that the RLs produced by $P$. aeruginosa RS6 were thermostable as they can maintain good emulsification activities after being subjected to autoclaving at $121{ }^{\circ} \mathrm{C}$ for $15 \mathrm{~min}$. Similar findings were reported by Abouseoud et al. (2007) who stated that the RLs produced by $P$. fluorescens were quite thermostable as they gave in good emulsification activities after being heated to $100{ }^{\circ} \mathrm{C}$. The thermal stability of RLs was also reported by Reddy et al. (2016), whereby $P$. aeruginosa DR1 supplemented with mango kernel oil was able to reduce the surface tension of water and the $E_{24}$ in the range from 30.0 to $31.3 \mathrm{mNm}$ and $70 \%$ on diesel, respectively.

\subsubsection{Surface tension measurement}

The unique properties of RLs such as dispersing, emulsifying, foaming, and wetting properties resulted from the ability of biosurfactants to reduce the surface tension through adsorption and development of biofilms at the interface (Deleu et al., 2015). The samples used for surface tension measurements were the cell-free supernatants of fermentation broths at 24,48 , and $72 \mathrm{~h}$ of fermentation. All samples, 1\% TWG, 1\% NTWG, and 1\% technical grade glycerol showed comparable results with $30.2 \mathrm{mN} / \mathrm{m}$, $29.4 \mathrm{mN} / \mathrm{m}$, and $30.4 \mathrm{mN} / \mathrm{m}$, respectively after $72 \mathrm{~h}$ of fermentation (Table 3). The surface tension obtained from this work was comparable to that of the study reported by Bharali et al. (2014), on RLs produced by $P$. aeruginosa JBK1 from crude glycerol which was $33.71 \mathrm{mN} / \mathrm{m}$. The crude RLs produced using all substrates were able to reduce the surface tensions more than the chemical-based surfactants; $1 \%$ Triton X-100, 1\% SDS, and $1 \%$ Tween 80 with values of $33.1 \mathrm{mN} / \mathrm{m}, 33.8 \mathrm{mN} / \mathrm{m}$ and $43.3 \mathrm{mN} / \mathrm{m}$, respectively. The present work was in agreement with a study reported by Aghajani et al. (2018) that the surface tension of RLs was lower compared to SDS due to the higher surface activity of RLs.

\subsection{Liquid chromatography-mass spectrometry (LC-MS) analysis}

Assignments of the mass spectral ions were compared to the structural analogues available in the literature (Abdel-Mawgoud et al., 2010). The LC-MS spectra of the partially purified RLs showed the dominance of mono-RLs with the distribution of intense protonated ions $[\mathrm{M}+\mathrm{H}]^{+}$at $\mathrm{m} / \mathrm{z} 307.13,357.04$ and 475.22 correspondings to Rha- $\mathrm{C}_{8: 1}$, Rha- $\mathrm{C}_{12: 2}$, and Rha- $\mathrm{C}_{8}-\mathrm{C}_{10}$, respectively (Fig. S3). The LC-MS spectra also detected di-RLs Rha-Rha- $\mathrm{C}_{10}-\mathrm{C}_{10}$ $\left(\mathrm{m} / \mathrm{z}\right.$ 525.26) and Rha-Rha- $\mathrm{C}_{10}-\mathrm{C}_{12}$ (m/z 679.35 and 701.24). These data clearly showed that the RLs produced by the strain RS6 were a

Table 3

Surface activity of RLs produced by $P$. aeruginosa RS6 at 24 h, 48 h, and 72 h of fermentation using different carbon sources.

\begin{tabular}{llll}
\hline \multirow{2}{*}{ Samples } & \multicolumn{3}{l}{ Surface tension $(\mathrm{mN} / \mathrm{m})$, Fermentation time $(\mathrm{h})$} \\
\cline { 2 - 4 } & $24 \mathrm{~h}$ & $48 \mathrm{~h}$ & $72 \mathrm{~h}$ \\
\hline 1\% TWG & $31.06 \pm 0.41$ & $30.73 \pm 0.60$ & $30.16 \pm 1.08$ \\
1\% NTWG & $30.73 \pm 0.36$ & $29.40 \pm 0.11$ & $29.38 \pm 0.32$ \\
1\% Glycerol & $31.65 \pm 0.02$ & $30.29 \pm 0.29$ & $30.36 \pm 0.01$ \\
Negative Control & $45.51 \pm 0.59$ & $44.82 \pm 0.68$ & $43.96 \pm 0.35$ \\
1\% Triton X-100 & 33.14 & & \\
1\% SDS & 33.78 & & \\
1\% Tween 80 & 43.34 & & \\
\hline
\end{tabular}

TWG $=$ Treated waste glycerol.

$\mathrm{NTWG}=$ Non treated waste glycerol. mixture of mono and di-RLs structural analogues. The majority of the RLs produced from various $P$. aeruginosa strains were mixed mono and di-RLs. The differences in the predominant RLs species might have resulted from the age of the culture, bacterial strains, substrate compositions, and culture conditions (Costa et al., 2010).

\subsection{Fourier transform infrared (FT-IR) spectroscopy analysis}

The chemical compositions of each component fractionated from the crude RLs using different carbon sources were preliminarily investigated by using the FTIR technique (Fig. S4). FTIR spectroscopy revealed important band spectra at 3390.21, 2928.31, 2855.37, 1728.98, and 1652.00-1066.52 $\mathrm{cm}^{-1}$ confirming the chemical structures of the biosurfactant to be identical to those of other reported RLs, which comprised of rhamnose rings and long hydrocarbon chains (Pornsunthorntawee et al., 2008). The wide spectral band at $3390.21 \mathrm{~cm}^{-1}$ corresponded to $-\mathrm{OH}$ extending of the hydroxyl group. The strong absorption peak at 2928.31 and $2855.37 \mathrm{~cm}^{-1}$ showed the existence of $-\mathrm{CH}$ aliphatic stretching bands while the existence of ester compounds was confirmed by the characteristic spectrum displayed at $1728.98 \mathrm{~cm}^{-1}$, conforming to $-\mathrm{C}=\mathrm{O}$ stretching vibrations of carbonyl groups. Result of the $-\mathrm{C}-\mathrm{O}-$ stretching band at $1652.00-1066.52 \mathrm{~cm}^{-1}$ confirmed the existence of the bonds formed between hydroxyl groups and carbon atoms in the chemical structures of the rhamnose rings.

\subsection{Antimicrobial activity of rhamnolipids}

The antimicrobial activities of RLs isolated from $P$. aeruginosa RS6 against Gram-positive (B. pumilus) and Gram-negative bacterial strains ( $P$. stewartii, $P$. ananatis, and E. mallotivora) were determined by the microdilution method. The growth inhibition was proportional to the concentrations of the RLs used (Table 4). The highest RLs concentration tested $(1 \mathrm{mg} / \mathrm{mL})$ showed substantial inhibition of the growth of both groups of bacteria with the values ranging from $37 \%$ to $77 \%$, respectively. Abalos et al. (2001) reported that the RLs M7 isolated from P. aeruginosa AT10 were active against both Gram-positive (Staphylococcus epidermis and Streptococcus faecalis) and Gram-negative microorganisms (E. coli and Serratia marcescens). Bacillus pumilus showed the highest degree of inhibition $57.51 \%-77.71 \%$ when exposed to RLs in the range of concentrations $0.25 \mathrm{mg} / \mathrm{mL}$ to $1 \mathrm{mg} / \mathrm{mL}$.

A previous study demonstrated that Gram-positive bacteria were more receptive to RL compared to Gram-negative bacteria (Ferreira et al., 2019). The difference in antimicrobial activity against Gram-positive and Gram-negative bacteria might be explained by the fact that Gram-negative bacteria possessed a unique outer lipopolysaccharide membrane which functioned as a barrier and protected the sensitive inner membrane and cell wall from toxic substances. Zhang et al. (2017) also mentioned that Gram-negative bacteria were more resistant because of the presence of the outer membrane that protected the cell.

Sotirova et al. (2008) reported that RLs could suppress the growth of Gram-positive and Gram-negative bacteria by two different mechanisms; 1 ) integration of RLs into the outer membrane of Gram-negative bacteria leading to the reduction of the lipopolysaccharide content, or 2) the formation of molecular aggregates by RLs in the membrane surface of Gram-positive bacteria leading to transmembrane pore formations as channels to the periplasm and therefore, modifying cell permeability. Furthermore, the antimicrobial properties of RLs corresponded to their amphiphilic characters which allowed for interactions with phospholipids that altered the cytoplasmic membrane permeability due to the formation of pores with the consequent leakage of cell components 
Table 4

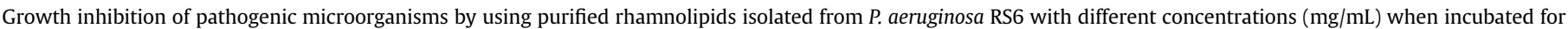
$24 \mathrm{~h}$.

\begin{tabular}{|c|c|c|c|c|c|}
\hline \multirow[t]{2}{*}{ Microorganism } & \multicolumn{5}{|c|}{ Rhamnolipid biosurfactant (mg/mL) } \\
\hline & 0.063 & 0.125 & 0.25 & 0.5 & 1.0 \\
\hline Bacillus pumilus & $15.65 \pm 7.26$ & $28.23 \pm 6.51$ & $57.51 \pm 34.35$ & $75.15 \pm 2.26$ & $77.71 \pm 1.04$ \\
\hline Pantoea stewartii & $39.16 \pm 4.64$ & $42.38 \pm 5.12$ & $43.30 \pm 4.24$ & $43.67 \pm 3.51$ & $44.07 \pm 2.00$ \\
\hline Pantoea ananatis & $28.44 \pm 1.57$ & $28.33 \pm 5.52$ & $29.30 \pm 4.31$ & $34.84 \pm 2.61$ & $37.02 \pm 2.59$ \\
\hline Erwinia mallotivora & $5.15 \pm 8.06$ & $9.53 \pm 8.66$ & $16.97 \pm 5.78$ & $41.46 \pm 5.12$ & $64.35 \pm 3.04$ \\
\hline
\end{tabular}

and cell death (Sánchez et al., 2006).

Rhamnolipids produced from $P$. aeruginosa also showed potential antifungal properties (Sha et al., 2012; Borah et al., 2016). Rhamnolipids produced by $P$. aeruginosa ZJU211 showed a potential cost-effective and environmental friendly biofungicide when $250 \mu \mathrm{g} / \mathrm{mL}-500 \mu \mathrm{g} / \mathrm{mL}$ of cell-free broth was applied on tomato plants in-vivo with declined disease severity (70-100\% recovery of infected plants by Phytophtora infestants) (Sha et al., 2012). In another report, RLs produced by $P$. aeruginosa SS14 were tested on Fusarium verticillioides and the used $50 \mu \mathrm{g} / \mathrm{mL}(\mathrm{mg} / \mathrm{L})$ of RLs caused complete suppression of ear and stalk rot disease in maize (Borah et al., 2016).

\subsection{Phytotoxicity of rhamnolipids}

Germination index (GI) is the combined measurement of relative seed germination and relative root elongation (Rufino et al., 2014). According to Luna et al. (2013), a GI value of $80 \%$ had been used to indicate the disappearance of the phytotoxicity of RLs. Different RL concentrations were prepared and used in the germination test of $V$. radiata. All concentrations of purified and analytical grade RLs did not show any inhibitory effects on seed germination and root elongation of V. radiata (Table 5). However, the concentration of $1500 \mu \mathrm{g} / \mathrm{mL}$ showed an inhibitory effect on seed germination and root elongation as the germination index dropped to $76.59 \%$ and $70.51 \%$, respectively. The increase in the concentration of RLs resulted in a decrease of the GI for V. radiata. Marecik et al. (2012) reported the GI for sorghum plant (Sorghum saccharatum) dropped to $41 \%$ at RLs concentration of $1200 \mu \mathrm{g} / \mathrm{mL}$. However, Millioli et al. (2009) reported slightly different findings whereby $1 \%$ and $1.5 \%$ RLs concentrations were both enough to inhibit the GI of lettuce (Lactuca sativa) by $80 \%$.

In the case of SDS treatment on $V$. radiata, seed germination, root elongation, and GI declined as compared to the RLs treatments and distilled water. Most of the seeds were severely retarded and did not germinate well. Chemically synthesized SDS was found to be more toxic with a GI value of $67.29 \%$ as compared to the RLs produced in the present work. Similar findings were demonstrated by Sharma et al. (2014) who stated that SDS treatment on black mustard (Brassica nigra) and wheatgrass (Triticum aestivum) contributed to lower GI values of $20 \%$ and $25 \%$ as compared to the RLs treatments and distilled water. Overall in this present work, the RLs did not induce phytotoxicity effects to the tested plant compared to the chemical-based- surfactant.

\subsection{Zebrafish toxicity assay}

The survival of zebrafish embryos exposed to different concentrations of RLs isolated from P. aeruginosa RS6 was determined at a specific time, as shown in Fig. 4. The survival rates of the zebrafish embryos showed a time and dose-dependent response as when these were increased, the number of survivors decreased. Rhamnolipids concentrations of $500 \mu \mathrm{g} / \mathrm{mL}$ and $250 \mu \mathrm{g} / \mathrm{mL}$ exhibited the highest toxicity since both resulted in $100 \%$ mortality of the zebrafish embryos at the 24 hpe. There was no further development of the embryos observed at those concentrations due to the acute lethal effects of the compounds present in the RLs. The morphological changes of zebrafish at $120 \mathrm{~h}$ of exposure to different RL concentrations are shown in Fig. S5.

The most common lethal effects and malformations detected were coagulation of embryos, non-hatching, and no somite formation. The lethal effects and malformations were initially observed after $24 \mathrm{~h}$ exposure. In comparison to chemical surfactants, the RLs used for the treatments indicated low acute toxicity for the tested zebrafish embryos with LC50 values of $72.97 \mu \mathrm{g} / \mathrm{mL}$ at $48 \mathrm{~h}$ of exposure and $57.44 \mu \mathrm{g} / \mathrm{mL}$ at $96 \mathrm{~h}$ of exposure. The present study is in line with the finding reported by Johann et al. (2016) which found that mono-RLs caused low acute toxicity to ecotoxicological model organism fish embryo (D. rerio) with LC50 values of $60 \mathrm{mg} / \mathrm{L}(60 \mu \mathrm{g} / \mathrm{mL})$. In contrast, Vaughan and van Egmond (2010) reported an acute toxicity ( $48 \mathrm{~h} \mathrm{LC50)}$ ) value of $5.8 \mu \mathrm{g} / \mathrm{mL}$ for an anionic surfactant; linear alkylbenzene sulphonate (LAS) in zebrafish embryos. Another chemical-based surfactant sodium dodecyl sulfate (SDS), as an anionic surfactant in many cleaning and hygienic products, has an LC50 value of $1.8 \mathrm{mg} / \mathrm{L}(1.8 \mu \mathrm{g} / \mathrm{mL})$ (Braunbeck et al., 2005; Johann et al., 2016). Moreover, there were no substantial effects or abnormal changes observed on the development of zebrafish embryos or larvae at RLs concentrations of $7.81 \mu \mathrm{g} / \mathrm{mL}$ to $31.25 \mu \mathrm{g} / \mathrm{mL}$.

According to Henn and Braunbeck (2011), the presence of

Table 5

Phytotoxicity evaluation of rhamnolipids at different concentrations on $V$. radiata (green gram).

\begin{tabular}{|c|c|c|c|}
\hline Rhamnolipids concentrations & Seed germination (\%) & Root elongation (\%) & Germination index (\%) \\
\hline SDS $(1000 \mu \mathrm{g} / \mathrm{mL})$ & $96.67 \pm 5.77$ & $69.14 \pm 12.82$ & $67.29 \pm 13.21$ \\
\hline Distilled water & $100 \pm 0$ & $100 \pm 0$ & $100 \pm 0$ \\
\hline $100 \mu \mathrm{g} / \mathrm{mL}$ & $100 \pm 0(100 \pm 0)$ & $126.24 \pm 14.73(160.95 \pm 9.59)$ & $126.24 \pm 14.73(160.95 \pm 9.59)$ \\
\hline $300 \mu \mathrm{g} / \mathrm{mL}$ & $100 \pm 0(100 \pm 0)$ & $114.44 \pm 13.21(114.15 \pm 8.59)$ & $114.44 \pm 13.21(114.15 \pm 8.59)$ \\
\hline $500 \mu \mathrm{g} / \mathrm{mL}$ & $100 \pm 0(100 \pm 0)$ & $99.88 \pm 12.69(99.46 \pm 7.87)$ & $99.88 \pm 12.69(99.46 \pm 7.87)$ \\
\hline $1000 \mu \mathrm{g} / \mathrm{mL}$ & $100 \pm 0(100 \pm 0)$ & $87.92 \pm 9.26(88.07 \pm 3.76)$ & $87.92 \pm 9.26(88.07 \pm 3.76)$ \\
\hline $1500 \mu \mathrm{g} / \mathrm{mL}$ & $100 \pm 0(100 \pm 0)$ & $76.59 \pm 11.02(70.51 \pm 13.71)$ & $76.59 \pm 11.02(70.51 \pm 13.71)$ \\
\hline
\end{tabular}

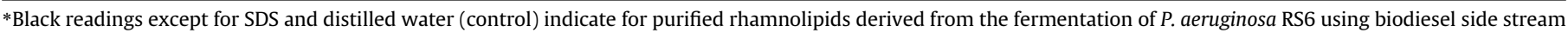
glycerol as carbon sources.

*Readings in close parenthesis ( ) indicate for analytical grade rhamnolipid purchased from AGAE Technologies (USA) as a standard. 


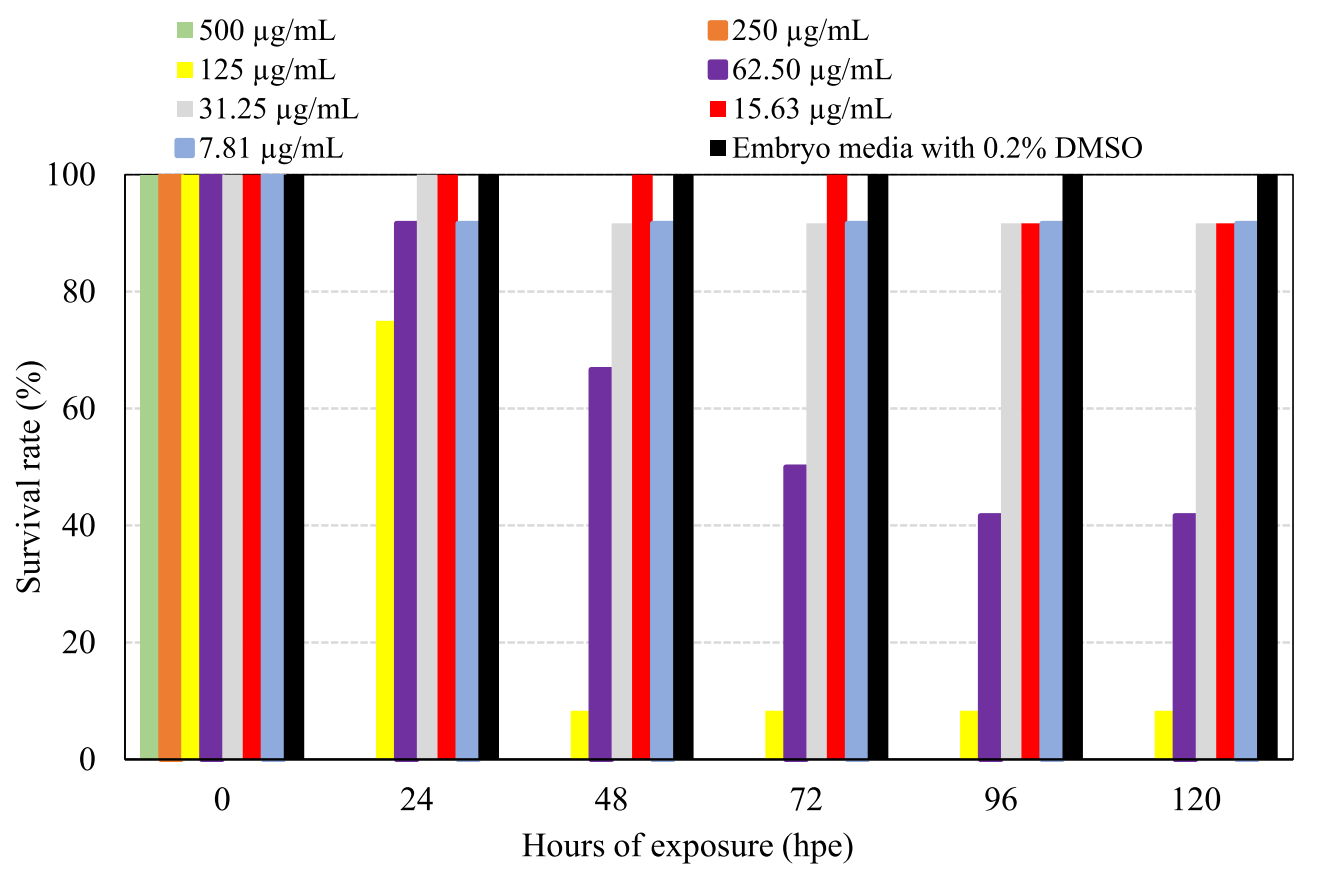

Fig. 4. Zebrafish survivability at $0-120 \mathrm{~h}$ of exposure to RLs treatment.

chorion (membrane containing pores) which surrounded the zebrafish embryos before hatching might provide a possible barrier to the diffusion of chemical substances. The pores in the chorion might be responsible for limiting the entrance into the embryos of chemicals substances of higher molecular weights (>3000 Da) (Braunbeck et al., 2014). However, acute toxicity of RLs to zebrafish embryos or larvae started to be detected when higher concentrations were applied and low molecular weight RLs could pass the barrier. The high concentration of RLs $(500 \mu \mathrm{g} / \mathrm{mL})$ applied in this study did not seem relevant to the environment, but it was still incorporated to ensure the threshold of detection for high toxicity. The lower concentrations tested were more relevant to the environment and were less toxic to the aquatic organism (zebrafish).

\section{Conclusions and future prospects}

Rhamnolipids production by $P$. aeruginosa RS6 utilizing biodiesel side stream waste glycerol was successfully carried out in this study. About $2.73 \mathrm{~g} / \mathrm{L}$ of RLs was produced with good emulsification activities $\left(E_{24}=>50 \%\right)$ on various vegetable oils and hydrocarbons. The RLs produced showed thermostable properties as they could maintain their $\mathrm{E}_{24}$ measurements after autoclaving at $121{ }^{\circ} \mathrm{C}$ with abilities to reduce the surface tension of water from $72.13 \mathrm{mN} / \mathrm{m}$ to $29.4-30.4 \mathrm{mN} / \mathrm{m}$ which were greater than the values obtained from chemical surfactants $(33.1-43.4 \mathrm{mN} / \mathrm{m})$. The molecular and structural properties of the RLs produced were confirmed by FT-IR and LC-MS to contain mono and di-RLs. The antimicrobial activities against Gram-negative and Gram-positive bacteria with values ranging from $37 \%$ to $77 \%$ of growth inhibition indicated that RLs could be used as green chemicals such as biopesticides. Toxicology tests on the tested seeds ( $V$. radiata) showed no phytotoxicity effects on seed germination compared to the chemical-based- surfactant, SDS. Furthermore, the RLs tested on zebrafish (D. rerio) embryos showed low acute toxicity with LC50 value of $72.97 \mu \mathrm{g} / \mathrm{mL}$ at $48 \mathrm{~h}$ of exposure. All in all, the RLs produced by P. aeruginosa RS6 can be competitive with the commercially available synthetic surfactants. The economics of rhamnolipids production is a major problem for commercialization amidst all the studies which showed their promising properties. The utilization of unrefined waste substrates and the ability to coproduce biosurfactants with other industrially important products need to be studied more critically especially for industrial systems using large fermentation bioreactors. Therefore, scaling-up of RLs production in large scale fermenters and the potential uses of this green material in agriculture such as its adoption as a biopesticide to mitigate plant pathogens are currently in progress.

\section{Credit author statement}

Shobanah Menon Baskaran: Investigation, Validation, Formal analysis, Methodology, Writing - original draft. Mohd Rafein Zakaria: Conceptualization, Methodology, Writing - original draft, Project administration, Supervision, Funding acquisition. Ahmad Syafiq Mukhlis Ahmad Sabri: Investigation, Validation. Mohd Shamzi Mohamed: Validation, Supervision, Writing - review \& editing. Helmi Wasoh: Project administration, Writing - review \& editing. Toshinari Maeda: Validation. Mohd Ali Hassan: Validation, Supervision, Writing - review \& editing. Ibrahim M. Banat: Validation, Supervision, Writing - review \& editing.

\section{Declaration of competing interest}

The authors declare that they have no known competing financial interests or personal relationships that could influence the work reported in this paper.

\section{Acknowledgements}

The authors would like to thank Dr. Dzarifah Zulperi for providing the plant pathogens used in the present study. This work was supported by the Universiti Putra Malaysia grant of GPBerimpak (9553700).

\section{Appendix A. Supplementary data}

Supplementary data to this article can be found online at 
https://doi.org/10.1016/j.envpol.2021.116742.

\section{References}

Abalos, A., Pinazo, A., Infante, M.R., Casals, M., García, F., Manresa, A., 2001. Physicochemical and antimicrobial properties of new rhamnolipids produced by Pseudomonas aeruginosa AT10 from soybean oil refinery wastes. Langmuir 17, 1367-1371.

Abdel-Mawgoud, A.M., Lépine, F., Déziel, E., 2010. Rhamnolipids: diversity of structures, microbial origins and roles. Appl. Microbiol. Biotechnol. 86, 1323-1336.

Abouseoud, M., Maachi, R., Amrane, A., 2007. Biosurfactant Production from olive oil by Pseudomonas fluorescens. Trends Appl. Microbiol. 340-347.

Aghajani, M., Rahimpour, A., Amani, H., Taherzadeh, M.J., 2018. Rhamnolipid as new bio-agent for cleaning of ultrafiltration membrane fouled by whey. Eng. Life Sci. $18,272-280$.

Aparna, A., Srinikethan, G., Smitha, H., 2012. Production and characterization of biosurfactant produced by a novel Pseudomonas sp. 2B. Colloids Surf. B Biointerfaces 95, 23-29.

Ashby, R.D., Nuñez, A., Solaiman, D.K.Y., Foglia, T.A., 2005. Sophorolipid biosynthesis from a biodiesel co-product stream. JAOCS, J. Am. Oil Chem. Soc. 82, 625-630.

Bharali, P., Singh, S.P., Dutta, N., Gogoi, S., Bora, L.C., Debnath, P., Konwar, B.K., 2014. Biodiesel derived waste glycerol as an economic substrate for biosurfactant production using indigenous Pseudomonas aeruginosa. RSC Adv. 4, 38698-38706.

Borah, S.N., Goswami, D., Sarma, H.K., Cameotra, S.S., Deka, S., 2016. Rhamnolipid biosurfactant against Fusarium verticillioides to control stalk and ear rot disease of maize. Front. Microbiol. 7, 1505.

Bradford, M.M., 1976. A rapid and sensitive method for the quantitation of microgram quantities of protein utilizing the principle of protein-dye binding. Anal. Biochem. 72, 248-254.

Braunbeck, T., Böttcher, M., Hollert, H., Kosmehl, T., Lammer, E., Leist, E., et al., 2005. Towards an alternative for the acute fish LC50 test in chemical assessment: the fish embryo toxicity test goes multi-species-an update. ALTEX 22, 87-102.

Braunbeck, T., Kais, B., Lammer, E., Otte, J., Schneider, K., Stengel, D., Strecker, R., 2014. The fish embryo test (FET): origin, applications, and future. Environ. Sci. Pollut. Res. 22, 16247-16261.

Chatzifragkou, A., Papanikolaou, S., 2012. Effect of impurities in biodiesel-derived waste glycerol on the performance and feasibility of biotechnological processes. Appl. Microbiol. Biotechnol. 95, 13-27.

Chayabutra, C., Wu, J., Ju, L.K., 2001. Rhamnolipid production by Pseudomonas aeruginosa under denitrification: effects of limiting nutrients and carbon substrates. Biotechnol. Bioeng. 72, 25-33.

Chen, S.-Y., Lu, W.-B., Wei, Y.-H., Chen, W.-M., Chang, J.-S., 2007. Improved production of biosurfactant with newly isolated Pseudomonas aeruginosa S2. Biotechnol. Prog. 23, 661-666.

Chi, Z., Pyle, D., Wen, Z., Frear, C., Chen, S., 2007. A laboratory study of producing docosahexaenoic acid from biodiesel-waste glycerol by microalgal fermentation. Process Biochem. 42, 1537-1545.

Costa, S.G.V.A.O., Nitschke, M., Lépine, F., Déziel, E., Contiero, J., 2010. Structure, properties and applications of rhamnolipids produced by Pseudomonas aeruginosa L2-1 from cassava wastewater. Process Biochem. 45, 1511-1516.

Deleu, M., Paquot, M., Blecker, C., 2015. Surface tension measurements on micellar systems. Encycl. Surf. Colloid Sci. 5119-5126.

Dharmadi, Y., Murarka, A., Gonzalez, R., 2006. Anaerobic fermentation of glycerol by Escherichia coli: a new platform for metabolic engineering. Biotechnol. Bioeng. 94, 821-829.

Eraqi, W.A., Yassin, A.S., Ali, A.E., Amin, M.A., 2016. Utilization of crude glycerol as a substrate for the production of rhamnolipid by Pseudomonas aeruginosa. Biotechnol. Res. Int. 1-9.

Farid, M.A.A., Hassan, M.A., Taufiq-Yap, Y.H., Shirai, Y., Hasan, M.Y., Zakaria, M.R., 2017. Waterless purification using oil palm biomass-derived bioadsorbent improved the quality of biodiesel from waste cooking oil. J. Clean. Prod. 165, $262-272$.

Ferreira, J. de F., Vieira, E.A., Nitschke, M., 2019. The antibacterial activity of rhamnolipid biosurfactant is pH dependent. Food Res. Int. 116, 737-744.

George, S., Jayachandran, K., 2013. Production and characterization of rhamnolipid biosurfactant from waste frying coconut oil using a novel Pseudomonas aeruginosa D. J. Appl. Microbiol. 114, 373-383.

González-Pajuelo, M., Meynial-Salles, I., Mendes, F., Soucaille, P., Vasconcelos, I., 2006. Microbial conversion of glycerol to 1,3-propanediol: physiological comparison of a natural producer, Clostridium butyricum VPI 3266, and an engineered strain, Clostridium acetobutylicum DG1(pSPD5). Appl. Environ. Microbiol. 72, 96-101.

Gudiña, E.J., Rodrigues, A.I., Alves, E., Domingues, M.R., Teixeira, J.A., Rodrigues, L.R., 2015. Bioconversion of agro-industrial by-products in rhamnolipids toward applications in enhanced oil recovery and bioremediation. Bioresour. Technol. 177, 87-93.

Henn, K., Braunbeck, T., 2011. Dechorionation as a tool to improve the fish embryo toxicity test (FET) with the zebrafish (Danio rerio). Comp. Biochem. Physiol. C Toxicol. Pharmacol. 153, 91-98.

Hogan, D.E., Tian, F., Malm, S.W., Olivares, C., Palos Pacheco, R., Simonich, M.T., Hunjan, A.S., Tanguay, R.L., Klimecki, W.T., Polt, R., Pemberton, J.E., Curry, J.E., Maier, R.M., 2019. Biodegradability and toxicity of monorhamnolipid biosurfactant diastereomers. J. Hazard Mater. 364, 600-607.

Ismail, W., Shammary, S. Al, El-Sayed, W.S., Obuekwe, C., El Nayal, A.M., Abdul Raheem, A.S., Al-Humam, A., 2015. Stimulation of rhamnolipid biosurfactants production in Pseudomonas aeruginosa AK6U by organosulfur compounds provided as sulfur sources. Biotechnol. Reports 7, 55-63.

Johann, S., Seiler, T.-B., Tiso, T., Bluhm, K., Blank, L.M., Hollert, Henner, 2016. Mechanism-specific and whole-organism ecotoxicity of mono-rhamnolipids. Sci. Total Environ. 548-549, 155-163.

Kondo, T., Kamikawa, M., Oka, K., 2015. Glycerin Purification Method. US Pat. App. 14.

Kronemberger, F.D.A., Santa Anna, L.M.M., Fernandes, A.C.L.B., Menezes, R.R. De, Borges, C.P., Freire, D.M.G., 2008. Oxygen-controlled biosurfactant production in a bench-scale bioreactor. Appl. Biochem. Biotechnol. 147, 33-45.

Lima, T.M.S., Procópio, L.C., Brandão, F.D., Leão, B.A., Tótola, M.R., Borges, A.C., 2011. Evaluation of bacterial surfactant toxicity towards petroleum degrading microorganisms. Bioresour. Technol. 102, 2957-2964.

Luna, J.M., Rufino, R.D., Sarubbo, L.A., Campos-Takaki, G.M., 2013. Characterisation, surface properties and biological activity of a biosurfactant produced from industrial waste by Candida sphaerica UCP0995 for application in the petroleum industry. Colloids Surf. B Biointerfaces 102, 202-209.

Luna, J.M., Rufino, R.D., Sarubbo, L.A., Lígia, R.R., José, A.T., Galba, M. de C.-T., Rodrigues, L.R.M., Teixeira, J.A.C., de Campos-Takaki, G.M., 2011. Evaluation antimicrobial and antiadhesive properties of the biosurfactant lunasan produced by Candida sphaerica UCP 0995. Curr. Microbiol. 62, 1527-1534.

Marchant, R, Banat, I.M, 2012a. Biosurfactants: a sustainable replacement for chemical surfactants? Biotechnol. Lett. 34, 1597-1605.

Marchant, R., Banat, I.M., 2012. Microbial biosurfactants: challenges and opportunities for future exploitation. Trends Biotechnol. 30, 558-565.

Marecik, R., Wojtera-Kwiczor, J., Lawniczak, L., Cyplik, P., Szulc, A., PiotrowskaCyplik, A., Chrzanowski, L., 2012. Rhamnolipids increase the phytotoxicity of diesel oil towards four common plant species in a terrestrial environment. Water. Air. Soil Pollut 223, 4275-4282.

Matar, G.M., Ramlawi, F., Hijazi, N., Khneisser, I., Abdelnoor, A.M., 2002. Transcription levels of Pseudomonas aeruginosa exotoxin A gene and severity of symptoms in patients with otitis externa. Curr. Microbiol. 45 (5), 350-354.

Matthijs, S., Coorevits, A., Gebrekidan, T.T., Tricot, C., Vander Wauven, C., Pirnay, J.P., Vos, P.D., Cornelis, P., 2013. Evaluation of oprl and oprL genes as molecular markers for the genus Pseudomonas and their use in studying the biodiversity of a small Belgian River. Res. Microbiol. 164 (3), 254-261.

Millioli, V., Servulo, E., Sobral, L., 2009. Bioremediation of crude oil-bearing soil: evaluating the effect of rhamnolipid addition to soil toxicity and to crude oil biodegradation efficiency. Glob. NEST J. 11, 181-188.

Moussa, T.A.A., Mohamed, M.S., Samak, N., 2014. Production and characterization of di-rhamnolipid produced by Pseudomonas aeruginosa TMN. Braz. J. Chem. Eng. 31, 867-880.

Narayan, M.S., Manoj, G.P., Vatchravelu, K., Bhagyalakshmi, N., Mahadevaswamy, M., 2005. Utilization of glycerol as carbon source on the growth, pigment and lipid production in Spirulina platensis. Int. J. Food Sci. Nutr. 56, 521-528.

Papanikolaou, S., Aggelis, G., 2002. Lipid production by Yarrowia lipolytica growing on industrial glycerol in a single-stage continuous culture. Bioresour. Technol. $82,43-49$.

Pereira, A.G., Pacheco, G.J., Tavares, L.F., Neves, B.C., Kronemberger, F. de A., Reis, R.S., Freire, D.M.G., 2013. Optimization of biosurfactant production using waste from biodiesel industry in a new membrane assisted bioreactor. Process Biochem. 48, 1271-1278.

Pornsunthorntawee, O., Wongpanit, P., Chavadej, S., Abe, M., Rujiravanit, R., 2008. Structural and physicochemical characterization of crude biosurfactant produced by Pseudomonas aeruginosa SP4 isolated from petroleum-contaminated soil. Bioresour. Technol. 99, 1589-1595.

Randhawa, K.K.S., Rahman, P.K.S.M., 2014. Rhamnolipid biosurfactants-past, present, and future scenario of global market. Front. Microbiol. 5, 1-7.

Reddy, K.S., Khan, M.Y., Archana, K., Reddy, M.G., Hameeda, B., 2016. Utilization of mango kernel oil for the rhamnolipid production by Pseudomonas aeruginosa DR1 towards its application as biocontrol agent. Bioresour. Technol. 221, 291-299.

Rooney, A.P., Price, N.P.J., Ray, K.J., Kuo, T.-M., 2009. Isolation and characterization of rhamnolipid-producing bacterial strains from a biodiesel facility. FEMS Microbiol. Lett. 295, 82-87.

Rufino, R.D., de Luna, J.M., de Campos Takaki, G.M., Sarubbo, L.A., 2014. Characterization and properties of the biosurfactant produced by Candida lipolytica UCP 0988. Electron. J. Biotechnol. 17, 34-38.

Saikia, R.R., Deka, S., Deka, M., Sarma, H., 2012. Optimization of environmental factors for improved production of rhamnolipid biosurfactant by Pseudomonas aeruginosa RS29 on glycerol. J. Basic Microbiol. 52, 446-457.

Sánchez, M., Teruel, J.A., Espuny, M.J., Marqués, A., Aranda, F.J., Manresa, Á., Ortiz, A., 2006. Modulation of the physical properties of dielaidoylphosphatidylethanolamine membranes by a dirhamnolipid biosurfactant produced by Pseudomonas aeruginosa. Chem. Phys. Lipids 142, 118-127.

Sha, R., Jiang, L., Meng, Q., Zhang, G., Song, Z., 2012. Producing cell-free culture broth of rhamnolipids as a cost-effective fungicide against plant pathogens. J. Basic Microbiol. 52, 458-466.

Sharma, D., Saharan, B.S., Chauhan, N., Bansal, A., Procha, S., 2014. Production and structural characterization of Lactobacillus helveticus derived biosurfactant ScientificWorldJournal 2014, 493548.

Silva, R., de, C.F.S., Almeida, D.G., Rufino, R.D., Luna, J.M., Santos, V.A., Sarubbo, L.A., 
2014. Applications of biosurfactants in the petroleum industry and the remediation of oil spills. Int. J. Mol. Sci. 15, 12523-12542.

Sluiter, A., Hames, B., Ruiz, R., Scarlata, C., Sluiter, J., Templeton, D., 2006. Determination of Sugars, Byproducts, and Degradation Products in Liquid Fraction Process Samples: Laboratory Analytical Procedure (LAP). Issue Date: 12/08/ 2006.

Smith, R.S., Iglewski, B.H., 2003. Pseudomonas aeruginosa quorum sensing as a potential antimicrobial target. J. Clin. Invest. 112, 1460-1465.

Smyth, T.J.P., Guazzaroni, M.E., Corte, N.L., 2010. Isolation and analysis of low molecular weight microbial glycolipids. Handb. Hydrocarb. Lipid Microbiol. 1, 1-6.

Sotirova, A.V., Spasova, D.I., Galabova, D.N., Karpenko, E., Shulga, A., 2008. Rhamnolipid-biosurfactant permeabilizing effects on gram-positive and gramnegative bacterial strains. Curr. Microbiol. 56, 639-644.

Strateva, T., 2008. Microbiological and Molecular-Genetic Investigations on Resistance Mechanisms and Virulence Factors in Clinical Strains of Pseudomonas aeruginosa. Medical Univ. of, Sofia, Bulgaria.

Supardan, M.D., Adisalamun Lubis, Y.M., Annisa, Y., Satriana Mustapha, W.A.W., 2017. Effect of co-solvent addition on glycerolysis of waste cooking oil. Pertanika J. Sci. Technol. 25

Suryanti, V., Hastuti, S., Wahyuningsih, T.D., Mudasir, M., Muliawati, D.I., 2009. Biosurfactants production by Pseudomonas aeruginosa using soybean oil as substrate. Indones. J. Chem. 9, 107-112.

Tiquia, S.M., Tam, N.F.Y., Hodgkiss, I.J., 1996. Effects of composting on phytotoxicity of spent pig-manure sawdust litter. Environ. Pollut. 93, 249-256.

Vaughan, M., Van Egmond, R., 2010. The use of the zebrafish (Danio rerio) embryo for the acute toxicity testing of surfactants, as a possible alternative to the acute fish test. ATLA Altern. to Lab. Anim. 38, 231-238.

Vivek, N., Sindhu, R., Madhavan, A., Anju, A.J., Castro, E., Faraco, V., Pandey, A. Binod, P., 2017. Recent advances in the production of value-added chemicals and lipids utilizing biodiesel industry generated crude glycerol as a substrate metabolic aspects, challenges and possibilities: an overview. Bioresour. Technol. 239, 507-517.

Wahdan, A., Fadel, A., Mabrok, M., 2020. New insights into the effect of Origanum extracts on the gene expression profiles of multidrug-resistant isolates of Pseudomonas aeruginosa retrieved from Oreochromis niloticus. Turk. J. Fish. Aquat. Sci. 20 (7), 507-519.

Wei, Y.-H., Chou, C.-L., Chang, J.-S., 2005. Rhamnolipid production by indigenous Pseudomonas aeruginosa J4 originating from petrochemical wastewater. Biochem. Eng. J. 27, 146-154.

Yang, F., Hanna, M.A., Sun, R., 2012. Value-added uses for crude glycerol - a byproduct of biodiesel production. Biotechnol. Biofuels 5, 13 .

Zhang, L., Jiao, L., Zhong, J., Guan, W., Lu, C., 2017. Lighting up the interactions between bacteria and surfactants with aggregation-induced emission characteristics. Mater. Chem. Front. 1, 1829-1835.

Zhang, X., Xu, D., Zhu, C., Lundaa, T., Scherr, K.E., 2012. Isolation and identification of biosurfactant producing and crude oil degrading Pseudomonas aeruginosa strains. Chem. Eng. J. 209, 138-146.

Zhu, C., Chiu, S., Nakas, J.P., Nomura, C.T., 2013. Bioplastics from waste glycerol derived from biodiesel industry. J. Appl. Polym. Sci. 130, 1-13.

Zhu, L., Yang, X., Xue, C., Chen, Y., Qu, L., Lu, W., 2012. Enhanced rhamnolipids production by Pseudomonas aeruginosa based on a $\mathrm{pH}$ stage-controlled fedbatch fermentation process. Bioresour. Technol. 117, 208-213. 